\title{
THE STUDY OF INTERNATIONAL REGIMES
}

Marc A. Levy

Princeton University

Princeton, New Jersey, USA

Oran R. Young

Dartmouth College

Hanover, New Hampshire, USA

Michael Zürn

Bremen University

Bremen, Germany

RR-96-7

June 1996

Reprinted from the European Journal of International Relations, Volume 1, Number 3, September 1995.

INTERNATIONAL INSTITUTE FOR APPLIED SYSTEMS ANALYSIS Laxenburg, Austria 
Research Reports, which record research conducted at IIASA, are independently reviewed before publication. Views or opinions expressed herein do not necessarily represent those of the Institute, its National Member Organizations, or other organizations supporting the work.

Reprinted from the European Journal of International Relations, Volume 1, Number 3, September 1995.

Copyright (c)1995 SAGE Publications Ltd.

All rights reserved. No part of this publication may be reproduced or transmitted in any form or by any means, electronic or mechanical, including photocopy, recording, or any information storage or retrieval system, without permission in writing from the copyright holder.

Printed by Novographic, Vienna, Austria. 


\section{Preface}

What happens to international environmental agreements once they are signed, and how does the implementation of such agreements influence their effectiveness? These are the questions that motivate the Implementation and Effectiveness of International Environmental Commitments (IEC) Project at the International Institute for Applied Systems Analysis (IIASA).

In this essay, Marc Levy, Oran Young, and Michael Zürn survey the literature on international "regimes." Regimes are social institutions that influence the behavior of states and their subjects. They consist of both informal and formalized principles and norms, as well as specific rules and procedures. Nearly all environmental regimes include one or more formal agreements among states. Scholarship over the last decade has elaborated how regimes are formed; this essay surveys that work and focuses on more recent scholarship that has turned from the formation of regimes to the question of what makes regimes "effective."

This review essay is one part of IEC's effort to build a database of the key variables related to the formation, operation, and effectiveness of international regimes. The database will enable the testing of hypotheses about regime effectiveness using evidence from a large number of cases simultaneously. Existing research has led to hypotheses and tests based on single case studies or small samples of cases, but conclusions have been difficult to apply to other cases because variables are left uncontrolled and the social processes are complex. In contrast, the IEC database effort will include all major variables related to effectiveness. The team will employ experts in each case to perform the coding, thus allowing for assessments (including subjective evaluations) of a wide range of data.

After two trial runs, the team is now finalizing the data protocol, as well as a manual that describes the principal questions in the data protocol and how they should be answered. The protocol and manual will refine the variables we are coding and their relationship to major hypotheses.

David G. Victor

Project Co-leader

International Environmental Commitments Project, IIASA 



\title{
The Study of International Regimes
}

\author{
MARC A. LEVY \\ Princeton University
}

\author{
ORAN R. YOUNG \\ Dartmouth College
}

\author{
MICHAEL ZÜRN \\ Bremen University
}

\begin{abstract}
The article surveys the literature on international 'regimes'. Regimes are social institutions that influence the behavior of states and their subjects. They consist of informal and formalized principles and norms, as well as specific rules, procedures and programs. The term is explicitly broad and captures the unwritten understandings and relationships, as well as the formal legal agreements, that influence how states and individuals behave in any given issue area. Scholarship over the last decade has elaborated how regimes are formed; this article surveys that work and focuses on more recent scholarship that has turned from the formation of regimes to the question of what makes regimes in general 'effective' and which 'types of regimes' are especially effective. The survey concludes with the identification of future research priorities in the field.
\end{abstract}

\section{Introduction}

More than a decade after the publication of the well-known special issue of International Organisation on regimes, the study of international institutions is alive and well. Perhaps the best proof lies in the length of this state-of-the-art report. Although a number of assessments of research on international regimes have appeared during the last decade, most confine their attention to certain aspects of international institutions. ${ }^{1}$ The excellent contribution of Stephan Haggard and Beth Simmons (1987), for instance, focuses on studies of regime formation (see also Efinger et al., 1993). The most recent contributions of this kind are more comprehensive in that they consider both regime formation and regime consequences. Even so, they address work done in specific academic communities (Rittberger, 1993b; Keohane, 1993) or in the context of specific projects (e.g. Haas et al., 1993; Mayer et al., 1993; Young and Osherenko, 1993). In this report, by 
contrast, we seek to make a more comprehensive evaluation, placing particular emphasis on recent developments and on future directions in research on international regimes. As will become apparent, research efforts in this field are shifting toward regime consequences in contrast to regime formation. They also make increasing use of theoretical insights drawn from analytic constructs outside the realm of rational choice models.

These developments in regime analysis reflect two underlying concerns that drive research on international institutions. The original analytic concern of regime analysis was to demonstrate, against neorealist claims, that institutions are a necessary ingredient of any theory of world politics. Today, this general point is more or less accepted, and the open questions are more specific: how do institutions affect world politics, how do institutions (including their formation) interact with actors (including their interest formation), and what are the independent consequences of regimes? The original normative concern, by contrast, was a desire to understand the consequences for the international economic order of a relative decline in American dominance. Although we now know that international regimes can form and become effective in the absence of a hegemon, the open questions are: how can new international institutions direct actor behavior in desired directions in various issue areas, how can international regimes foster learning on the part of participating actors, and how can international institutions restructure domestic institutions? In this connection, many recent studies focus on international environmental regimes, an area conducive to the analysis of the new analytical and normative concerns underlying regime analysis.

This report reflects these recent developments in regime analysis. In this sense, it may appear that the examples we use to illustrate theoretical arguments are unbalanced in one way or another. At the same time, the report is more balanced than previous surveys in covering the four sets of questions driving most research on international institutions:

1. Under what conditions and through what mechanisms (why and how) do international regimes come into existence? Can institutions form in the absence of a power monopoly and without the participation of a hegemon? Is it possible for international regimes to come into existence when they are needed or do they emerge only in special situations? What kinds of processes lead to the formation of international regimes? Do different types of regimes follow different paths of regime formation?

2. Do regimes persist even when the circumstances in which they came into existence change? To what extent are they independent of the exogenous forces that form them? Are regimes robust enough to survive a deterioration of the overall relationship among the participants and, at the 
same time, flexible enough to adapt to changes? What mechanisms give regimes independence and robustness? Are regimes featuring specific attributes more persistent and robust than others? What makes some regimes more flexible than others?

3. What consequences of regimes for state behavior and problem-solving can we observe? Do regimes serve the goals that led to their creation? What stated goals do regimes usually espouse? Are the stated goals indeed those that are pursued? Under what conditions do regimes make a difference? Are certain types of regimes more conducive to goal attainment than others? Through what mechanisms do regimes influence outcomes?

4. What long-term effects on national political systems and the structure of world politics do regimes have? Why and how do such effects occur? Are individual participants aware of these long-term consequences? What are the consequences of regimes with regard to traditional notions of democracy? How do they affect social and political constellations in the participating countries? Do regimes play a civilizing role in world politics, and if so, how?

Although these four sets of questions are clearly interrelated, answering them may require different strategies of inquiry. In this sense, regime analysis may be less straightforward and focused than is usually assumed. Yet the different strands of regime analysis are complementary in that we must provide satisfactory answers to all four sets of questions to develop a comprehensive 'regime theory' that meets the underlying concerns of regime analysis. In this article, we summarize and draw together international research on regimes and institutions against the background of what an ideal 'regime theory' would be able to tell us. This procedure serves two ends. It provides a state-of-the-art report that evaluates research on regimes over the last decade and identifies blank spots in existing knowledge. Our contribution also constitutes a basis for building a 'database of international regimes', an endeavor in which we are currently involved. Although answering different questions associated with regime analysis may require different research strategies, it is helpful to have an inventory encompassing the information gathered in research on regimes along all dimensions. The development of an appropriate format for such an inventory requires a profound knowledge of all relevant work as well as a good sense of future directions in regime analysis. Since three individuals can at best approximate these requirements, we invite readers of this article to provide input regarding the format and content of the regimes database.

Before addressing the major research questions that drive regime analysis, it is important to focus on defining international regimes and distinguishing among different types of regimes. These matters are not important as ends 
in themselves. But they are instrumental in answering all the questions raised in regime analysis.

\section{Defining and Classifying International Regimes}

In a recent volume of the International Social Science Journal, three European scholars evaluate the contributions of regime analysis to our understanding of international organization. All three are highly critical of what they call 'regime theory'. One of their major criticisms concerns the definition of regimes: 'In fact, the regime concept, as used by adepts of this approach, has never been clearly defined. ... Definitions of the concept cover a mixed bag of subjects reflecting different meanings' (de Senarclens, 1993: 456). In a generally balanced rejoinder, Helen Milner concedes that 'Defining a regime remains a difficult task; one could say that despite the consensus definition proposed by Krasner a decade ago, the concept is still essentially contested' (Milner, 1993: 493-4). Given this background, it is important to tackle the definitional issue directly. In this section, we also offer some thoughts on distinctions among different types of international institutions that are likely to prove theoretically useful.

\subsection{What Are International Regimes?}

Critics have attacked the often cited consensus definition (Krasner, 1983a) ${ }^{2}$ for two major reasons. One criticism points to the difficulty in differentiating the four components of regimes (indistinguishable components); the other characterizes the standard definition as vague because it does not resolve differences among those who study international regimes regarding the boundaries of the universe of cases (vagueness). In addressing these criticisms, we do not seek to offer another alternative. Rather, we endeavour to modify and concretize the consensus definition in a way that accommodates different understandings but also allows analysts to distinguish among them. The goal is to be inclusive enough to permit comparisons among sets of regimes defined in somewhat different ways but, at the same time, to be precise enough to make these comparisons meaningful.

Vagueness. There is broad agreement about at least two elements of the consensus definition. First, it treats regimes as social institutions in the sense of stable sets of rules, roles and relationships. ${ }^{3}$ Second, it characterizes regimes as issue-area specific in contrast to the broader or deeper institutional structure of international society as a whole. Examples of deep structure include the ideas of pacta sunt servanda and diffuse reciprocity. 
Although it may be true that much of regime theory misses 'the crucial link between the costs and benefits of specific legal rules and the role of international law as constitutive of the structure of the state system itself' (Hurrell, 1993: 59), many studies of regimes have pointed to this institutional embeddedness as a topic requiring more attention (Ruggie, 1983; Young, 1989a: 13).

Given this substantial consensus in conceptual terms, we turn to controversies about the adequacy of efforts to operationalize the concept of international regimes. Much of the criticism of definitional fuzziness points to the problem of knowing regimes when we see them rather than knowing what we are talking about in discussions of international regimes. Whereas an informal understanding of what makes up an international regime is often sufficient to formulate sensible research designs for 'in-house' projects, the cumulation of knowledge based on comparisons of the findings of different projects requires a more formal operationalization.

Since rules are more well defined and concrete than principles and norms, they constitute the right starting-point for operationalizing international regimes. The term 'rules' is ambiguous because it is used both in the sense of 'as a rule' (regularity) and in the sense of 'follow the rule' (prescription). Given the basic thrust of regime analysis as a tool for understanding international cooperation and the role of norms in the pursuit of cooperation, there is a need to go beyond merely routinized or patterned behavior. ${ }^{4}$ The principal claim of regime analysis is that states may generate institutions in identifiable issue areas that affect their behavior and foster cooperation, even if short-term interests would dictate deviation. Patterned behavior, by contrast, may also emerge in the absence of institutions, and it does not presuppose cooperation.

Two procedures for operationalizing the consensus definition have received attention. According to the first, we should look for explicit rules or injunctions (with an embodiment independent of the actors). The second suggests adding an element of observable behavior to the definition (Haggard and Simmons, 1987: 494; Wolf and Zürn, 1986: 205). Both operationalizations have serious drawbacks when taken to extremes. The substantive procedure is in danger of circular reasoning - identifying regimes on the basis of observed behavior and then using regimes to explain this behavior. In addition, this approach requires difficult causal inferences about regimes in order to identify them. On the other hand, a purely formal operationalization includes numerous 'paper regimes' or, more generally, an inflated universe of cases.

A closer inspection reveals that these are not the only options. The debate actually involves two separable dimensions. With respect to each of these dimensions, the literature includes different notions of what is needed before 
Marc A. Levy et al.

\begin{tabular}{|c|c|c|}
\hline \multirow[b]{3}{*}{ Formality } & \multirow{2}{*}{\multicolumn{2}{|c|}{$\begin{array}{l}\text { Figure } 1 \\
\text { Regime Definitions } \\
\text { Convergence of Expectations }\end{array}$}} \\
\hline & & \\
\hline & Low & High \\
\hline Low & no regimes & tacit regimes \\
\hline High & dead letter regimes & classic regimes \\
\hline
\end{tabular}

we can speak about the existence of an international regime. The first dimension highlights the degree of formality of the rules, whereas the second features the degree to which the expectations of actors converge. Taken together, we can use these dimensions to construct a matrix that displays different notions of international regimes (see Figure 1).

We do not think it makes sense to use the term 'regime' in the absence of both a minimum degree of formalization and a minimum degree of convergence in expectations. The northwest cell of Figure 1 is therefore empty. 'Dead letter regimes' feature the existence of explicit rules including both substantive and procedural prescriptions articulated in written form, whether or not they are legally binding. Although the numerous truce agreements in Bosnia are cases featuring explicit rules that cast doubt on the value of this operationalization, the fact that it is easy to identify explicit rules makes this criterion attractive (Keohane, 1993: 26-9). The term 'tacit regimes', by contrast, refers to those cases in which regular but implicit references to informal rules are common along with behavior that is consistent with some independently inferred rules (Lipson, 1991). The balance of power system in 19th-century Europe and the system of spheres of influence among the superpowers after World War II are examples of this type of regime. 'Classic regimes' exist in those issue areas in which in addition to explicit rules and regular references to them, rule-consistent behavior is widespread. Rule-consistent behavior can be inferred when (1) clear violations remain the exception, (2) parties harmed by violations protest against them by implicitly or explicitly referring to the agreed upon rules and (3) violators do not deny the rules and norms referred to in these protests. ${ }^{5}$ We use the term 'classic regime' for such cases since the presence of all indicators - explicit rules, regular references to the rules, ruleconsistent behavior - ensures that virtually every regime analyst would agree that international regimes exist under these conditions; the study of 
these cases undoubtedly constitutes the core of regime analysis. The General Agreement on Tariffs and Trade (GATT) regime and the ozone regime are well-known cases in point.

We do not think that it is sensible to push for exclusive reliance on one of these three approaches to operationalization. Each approach has significant virtues. We therefore propose to consider all three notions of regimes in our survey of the field. Using a procedure involving several explicitly specified entry criteria will allow scholars to construct arguments about both the formation and the impact of international regimes employing different universes of cases. So long as individual analysts are careful to state clearly the universe they are referring to, this procedure should facilitate the growth of knowledge rather than becoming a source of confusion. ${ }^{6}$

Indistinguishable Components. The second criticism asserts that distinctions among principles, norms and rules lack intersubjective meaning. This leads to the suggestion that the distinction be dropped in favor of focusing exclusively on explicit injunctions. There is something to be said for this argument. Yet drawing such distinctions may still be heuristically useful, if we are able to provide some guidelines for discrimination. Principles involve goal orientations and causal beliefs cast at the level of general policy arenas, like economics, security or the environment. The economic regimes created by the Western states after 1945, for example, were based on the principle of 'embedded liberalism' (Ruggie, 1983). Norms describe general rights and obligations that operate mainly on the level of issue areas. But they are still so general that it is often impossible to determine whether or not specific actions violate them. It is hard to say, for example, whether states have really followed the norm of 'conditional reduction of trade barriers'. Rules are the most concrete of the components referred to in the consensus definition. They are often stated explicitly in the formal agreements on which regimes are commonly based, and they facilitate assessments of implementation and compliance. Rules may, for example, specify explicit targets and timetables for tariff reductions called for in a specific industrial sector (Keohane, 1984; 58; Krasner, 1983b: 4-5). Of course, these are approximate distinctions. Yet the resultant imprecision is not critical for purposes of identifying regimes since differentiating among principles, norms and rules does not figure in defining regimes in the first place.

Since the cost of retaining these distinctions is low, we ask whether their use has potential benefits. We see two advantages. These distinctions contribute to the descriptive richness that is a major strength of regime analysis, acknowledged by the critics of this research program. ${ }^{7}$ Also, and more importantly, distinguishing among principles, norms and rules makes it 
possible to classify regimes in ways that may prove useful in explaining regime formation and regime consequences.

To sum up, we suggest defining international regimes as social institutions consisting of agreed upon principles, norms, rules, procedures and programs that govern the interactions of actors in specific issue areas. As such, regimes give rise to recognized social practices in international society. Defined in this way, regimes are distinct from international organizations which are material entities ${ }^{8}$ from the broader structure of international society which consists of encompassing principles of conduct valid across all issue areas, and from the world order which encompasses the sum of all the institutional arrangements operative at the international level. On this account, international regimes may or may not include conventions. In his well-known study, Lewis (1969) separates conventions from institutions on the basis of the constellation of interests in which they are embedded (see also Schotter, 1981; Snidal, 1985a; Ullmann-Margalit, 1977). But when regimes are defined and operationalized in terms of social rules, it is not feasible to use the social environment of the rules to separate conventions (which also contain rules) from regimes. ${ }^{9}$ In effect, various characteristics of the social environment - the basis of the distinction between conventions and other institutions - become criteria which we can use to subdivide the overall universe of international regimes into subsets.

\subsection{Classifications of Regimes}

The principal reason for classifying regimes is to facilitate the formulation of hypotheses about regime formation and regime consequences. Thus, it is easy to envision the development of generalizations applying to subsets of regimes but not to the entire universe of international regimes. To strengthen the institutionalist point of view, moreover, we ought to be able to account for variations in the consequences of international regimes by referring to the character of these institutions (endogenous variables) instead of by referring only to the causal factors used to explain variation among regimes in the first place (exogenous variables). Among students of domestic politics, the most convincing demonstrations that different institutional arrangements matter involve showing how different types of political institutions lead to different outcomes. When Maurice Duverger developed the hypothesis that polities with majority voting lead to two-party systems whereas proportional voting generates multi-party systems, for example, he correctly focused on institutional differences to explain divergent outcomes. Other conceivable explanations of the number of parties in a given political system, such as the number of social cleavages within a society, might affect both the voting system and the party system. But focusing on these 
cleavages does not help us to understand the consequences of the political institutions. If institutions matter - at a minimum by mediating between underlying structures and outcomes in an issue area - we should be able to understand outcomes in that area by highlighting these institutional arrangements.

All discussions of regime classifications confront a common problem. Innumerable regime attributes or properties can be used for classificatory purposes, and we lack good a priori criteria regarding what sorts of classifications will prove useful in future research. So far, empirical research on international regimes has not made systematic and explanatory use of regime classifications. Therefore, we cannot report replicated findings about typical formation paths or consequences of specific types of regimes. We draw the following conclusion from this. Systematic and sustained efforts to classify regimes constitute a blank spot in our understanding of international regimes which deserves more research. Given this situation, it seems sensible to start by focusing on variations in 'core properties' of regimes. These are attributes that are explicitly mentioned in defining regimes. In the following paragraphs, then, we first take up the principal regime components (principles, norms, rules, programs and procedures), and then move on to classifications pointing to variations in types of actors as well as to differences in the issue areas to which the rules apply.

Principles and Norms. Classifying international regimes on the basis of different types of principles and norms constitutes the most familiar approach to this issue.

1. Regimes may or may not involve functional differentiation. According to sociological theory, regimes featuring a principled (as opposed to a practical) differentiation of roles among the participants (e.g. flag vs. port vs. coastal states or upstream vs. downstream states) exhibit higher degrees of institutionalization. We therefore expect that functionally differentiated regimes will be more difficult to create; they come into existence only as part of larger institutional networks. Yet once established, we expect them to be more influential in terms of consequences and to display greater robustness.

2. A comparatively well-established idea classifies regimes in terms of the assignment of property rights or the mode of allocation determined by their principles. Thus, we can distinguish among regimes serving to promote internationalization (e.g. the international sea-bed regime), nationalization (e.g. exclusive economic zones) and free access and exchange (e.g. international waters). Perhaps the most prominent hypothesis associated with this classification is the theory of hegemonic stability, which is not only 
a theory of regime formation but also predicts the emergence of regimes facilitating free exchange and access under conditions of high concentration in overall structural power (Krasner, 1976). Some also argue that this classification is especially relevant to the distributional effects of regimes. Liberal or market-oriented regimes, which feature free exchange and access, may cause asymmetric distributions of resources between states and within states. Yet market-oriented regimes are expected to be particularly efficient, so that they increase overall social welfare. State-oriented regimes, which feature national property rights, probably reduce inequalities in the distribution of resources between states, but they do not necessarily alter domestic inequalities. In contrast, regimes that assign property rights to international authorities may allow for a more equal distribution of resources between and within states, but they are also likely to foster serious inefficiencies, as in the case of the common agricultural policy of the European Union (Krasner, 1985: 5-14; Wolf, 1991; Zürn, 1987: 45-6).

3. John Ruggie has developed an interpretation of multilateralism that emphasizes the underlying principle of cooperation rather than the number of participants involved. Multilateralism, on this account, describes institutions that build on (a) anti-discrimination as a generalized principle of conduct, (b) the principle of indivisibility and (c) the principle of diffuse reciprocity, where these elements are treated as an indivisible ensemble (Ruggie, 1992: 570-3; see also Caporaso, 1992: 599-632). Accordingly, multilateral institutions can only prevail when multilateralism reflects a dominant normative orientation in the domestic practices of a hegemon or, more generally, the leading members of a regime (Ruggie, 1992: 592). With regard to regime consequences, liberal social theory suggests that multilateral regimes will produce more benign effects than others.

4. It is possible also to classify regimes in terms of goal orientation. We may distinguish regimes that serve mainly to increase the utility of regime participants in absolute terms (internal regimes), for example, from those that seek to improve the position of members relative to outsiders (external regimes) (Zürn, 1987: 40-5). To operationalize this distinction, we can look at membership rules. A related distinction separates open institutions (e.g. the UN), conditionally open institutions (e.g. IMF, GATT) and institutions with restricted membership (e.g. NATO, OPEC, EU), with the latter being most externally oriented (Keohane, 1993: 39).

Rules. Efforts to classify regimes in terms of different types of rules commonly draw on judicial and sociological theory:

1. In her well-known work Governing the Commons. Elinor Ostrom argues that 'Institutional rules are prescriptive statements that forbid, 
require, or permit some action or outcome. One of the three deontic operators - forbid, require, permit - must be contained in a statement for it to be considered as a rule' (Ostrom, 1990: 139). ${ }^{10}$ We can therefore classify regimes on the basis of whether they highlight prohibitions, requirements or permissions. Although we do not know of existing hypotheses, this distinction may shed light on regime formation and consequences in much the same way that Theodore Lowi's parallel distinction among regulative, distributive and redistributive policies has contributed to understanding different policy-making processes in domestic political systems (Lowi, 1964). We may expect also that requiring rules will be the most hotly contested, whereas permitting rules are much easier to implement, and prohibitions lie in between.

2. Thomas Franck has argued that international rules exert a normative pull toward compliance to the extent that they are legitimate. Consequently, he asks what observable characteristics of rules increase or decrease their legitimacy and therefore their pull toward compliance. Four characteristics of rules appear to enhance legitimacy: (a) determinateness and clarity, (b) symbolic validation within the participating community, (c) internal coherence and $(\mathrm{d})$ vertical links between a primary rule of obligation, which is the system's workhorse, and a hierarchy of secondary rules, which identify the sources of rules and establish 'normative standards that define how rules are to be made, interpreted, and applied' (Franck, 1990: 184). Regime analysis should seek to test this complex hypothesis carefully, not least for the contributions this effort can make to the debate between rationalists and reflectivists.

3. A regime may be described as strong when its rules are dense, specific and cover a broad range of activities (Keohane, 1993: 41-3). Clearly, weak regimes will be limited in terms of problem-solving capacity. Nonetheless, a strong regime may encounter compliance problems, at least in the short run, since the number of inconvenient commitments increases with the number and breadth of rules. If a regime exhibiting high rule density survives its first challenges (e.g. a change of governments, deterioration in overall relationships among members), however, it can be expected to be resilient in subsequent periods, since the rules have a stabilizing effect upon each other.

Procedures and Programs. Typologies of regimes featuring distinctions among decision-making procedures are numerous. Work on international organizations that highlights the effects of different voting systems (Freeman and Cannizo, 1981; Lister, 1984) or the secretariat's role in decision-making (Cox and Jacobson, 1973) is relevant here. Yet three 
other characteristics of decision-making procedures seem to us especially important.

1. If a regime that is initially weak (as defined above) is accompanied by a decision-making procedure that is autonomous in the sense of being able to revise rules, the regime is apt to foster learning at the international level and to lead to the establishment of new rules. Institutions have strong decision-making procedures if changes are carried out according to an $e x$ ante plan or, in other words, a procedure spelled out in the regime itself (Kenneth Shepsle, cited in Ostrom, 1990: 58). We may call such arrangements evolutionary regimes. Regimes of this type may turn out to be successful as problem-solvers in the long run by giving a strong impetus to learning. Many environmental protection arrangements are good examples of this regime type (Haas et al., 1993; Breitmeier et al., 1993). In contrast, reliant or static regimes, where decision-making procedures are not sufficiently developed to react to external changes, can turn out to be brittle in the face of external changes. They can be expected as well to have a low impact with regard to learning. Still, regimes of this kind may prove effective in managing prolonged conflicts of a static nature. A case in point is the Berlin regime (Schwarzer, 1990).

2. We can speculate as well about the character of collective-choice mechanisms in autonomous regimes. A rough distinction separates institutions in which most members affected by the rules participate in modifying them (e.g. the SALT-based regime) and those in which a few privileged members have the authority to modify the rules (e.g. the IMF-based regime). We would expect the distribution of benefits flowing from cooperation to vary in terms of this difference.

3. Regimes also differ with regard to their compliance mechanisms, including monitoring, sanctioning, and dispute-resolution procedures. Where compliance mechanisms are highly developed, we would expect that the regime was established to solve what game theory characterizes as a dilemma. Regimes with strong compliance mechanisms can be expected to alter the behavior of regime participants considerably. On the other hand, weak monitoring, sanctioning and dispute-resolution procedures should characterize regimes emerging in situations resembling games (Martin, 1992; Stein, 1983); they will alter behavior only moderately. Despite the emphasis rational choice theorists place on them (Coleman, 1990: Chs 10-11; Ostrom, 1990), the analysis of compliance mechanisms remains an underdeveloped dimension of regime analysis.

Actors and Issue Areas. International regimes govern the interactions of actors in specific issue areas. It follows that regimes may vary with respect to 
the number and type of actors involved as well as the type and scope of issues covered or, in other words, the problem structure. The number of actors participating in an international regime may vary from two to the complete set of states. Whereas it is more difficult to create regimes with many actors, we do not know much about the effects of numbers on regime consequences. Still, it is more or less accepted that the participation of non-state actors (e.g. Greenpeace or Amnesty International) and epistemic communities, at least in the rule-implementation stage, does improve the effectiveness of environmental regimes. We can expect as well that learning will be positively affected by agreements that include non-state actors (Haas, 1992; Haas et al., 1993).

Little effort has been made so far to use distinctions involving problem structure to account for differences in regime consequences, though they have proved useful in accounting for differences in the likelihood of regime formation. Some analysts argue, however, that when the principles and norms of a regime are nested together with other regimes, the regime becomes highly resilient in the face of deterioration in the overall relationships to which it relates (Keohane, 1984; Müller, 1993b). Furthermore, where networks of regimes link the same set of participants, actors' perceptions of each other's behavior are more likely to be affected than where regimes are isolated.

This quick survey points to a number of ways to classify regimes that may be useful in efforts to understand their formation and their consequences. Yet most of these distinctions remain unexplored empirically. The development and use of regime typologies require a research design emphasizing comparisons among cases, a point of considerable importance given that much research on international regimes to date has taken the form of single case studies or structured, focused comparisons using a small number of cases. Only by studying a larger number of cases comparatively can we develop regime typologies that contribute significantly to our understanding of the role of international regimes in world politics.

\section{Regime Formation}

Regime formation, a subject that encompasses the reformation of existing institutional arrangements as well as the creation of new institutions where none have previously existed, has emerged as one of the central concerns of the 'new institutionalism' in International Relations (Keck, 1991; Moravcsik, 1992; Zacher and Matthew, 1992; Young, 1994). The study of regime formation can be broken down into three distinct - albeit interrelated - topics (Young and Osherenko, 1993). There is, first, the basic question of whether those parties interested in a given issue succeed in 
Marc A. Levy et al.

forming a regime or fail to reach closure on the terms of a mutually agreeable institutional arrangement. In cases where regime formation is ultimately successful, it is pertinent to proceed to a second topic by asking how long it takes to move from the appearance of an issue on the active international agenda to the conclusion of an agreement setting forth the terms of a regime. As the cases of East-West relations in Europe (Rittberger and Zürn, 1990), Antarctica and the northern fur seal attest (Beck, 1986; Mirovitskaya et al., 1993), it is not uncommon for two decades or more to elapse in the effort to reach agreement on the terms of an international regime, a matter of growing concern to those who believe we have entered an era of rapidly escalating environmental and other crises. Third, we want to ask about the substantive content or character of the regimes created to deal with international issues. This is a matter of particular concern to those who emphasize the importance of tailoring the features of specific institutional arrangements to the nature of the problems they are created to solve. A comprehensive theory of regime formation should allow us to account for success or failure in efforts to establish regimes, the time it takes to reach agreement in successful cases, and the substantive provisions set forth in constitutional contracts devised for individual regimes.

The major analytic issues raised in the study of regime formation can be grouped into six broad categories: behavior of the actors in regime formation, processes of regime formation, stages of regime formation, driving social forces, cross-cutting factors and multivariate models.

\subsection{Actors and Actor Behavior}

Most students of international regimes accept the view that the members of these arrangements are states. But this does not mean that non-state actors and even individuals are irrelevant to processes of regime formation; far from it. Increasingly, non-state actors loom large in framing issues for inclusion on the international agenda and in focusing attention on specific issues in a way that induces states to work toward the creation of institutional arrangements dealing with them. Today, representatives of non-state actors frequently serve as members of national delegations working on the provisions of international regimes. Often they are also accepted as observers in their own right. All this has important consequences for the nature of the political dynamics involved in both the initial creation and the reformation of international institutions. But it does not alter the fact that regimes are properly understood as social practices created to guide interactions among the members of international society (that is, states) in identifiable issue areas.

Early studies of regime formation treated participating states as unitary 
actors seeking to maximize some sort of national interest. But this practice has given way to a number of newly emerging lines of analysis emphasizing the fact that the participants in regime formation are complex collective entities. Perhaps the most influential of these is the study of two-level games, a perspective that emphasizes the linkages between bargaining among states and bargaining within individual states over positions to be taken at the international level (Putnam, 1988; Evans et al., 1993). But several other lines of analysis are noteworthy in this connection as well. Some writers have examined the cultural and institutional roots of behavioral differences among states participating in processes of regime formation (Vernon, 1993). Others have focused on the role of scientists in developing the positions of states on a range of issues including the loss of stratospheric ozone, threats to biological diversity and climate changes (Susskind, 1994). Still others have proposed the idea of regime-conducive foreign policies and endeavored to identify links between various features of domestic politics and the articulation of foreign policies of this type (Zürn, 1993).

\subsection{Processes of Regime Formation}

Three distinct visions of the process of regime formation have emerged in the literature on international regimes: self-generation, negotiation and imposition (Young, 1983). All regimes are expected to feature explicit though not necessarily formal - rules in the end, ${ }^{11}$ but the processes involved in reaching this point can vary greatly. Thus, a self-generating or spontaneous regime is one that emerges through some process of converging expectations that does not require conscious efforts on the part of those who become participants in the resultant social practice. Much favored by political conservatives because it obviates the need for institutional design or social engineering, this process is often described as a means of producing order without law (Ellickson, 1991). A negotiated regime is one that arises from a conscious process of bargaining in which the parties engage in extended efforts to hammer out mutually agreeable provisions to incorporate into an explicit agreement. Thought by many, including most practitioners, to be the primary process of regime formation in international society, negotiation has become a familiar feature of the landscape of international institutional affairs. An imposed regime, by contrast, is an arrangement that is favored by a single powerful actor (or, in some cases, a small coalition of powerful actors) that succeeds in inducing others to accede to its institutional preferences. Favored by those who think in terms of structural power and look for ruling elites as the prime movers in the creation of institutions, imposition can also be interpreted more benignly as a process through which leading actors supply institutional arrangements 
looked upon as public goods to privileged groups (Olson, 1965; Snidal, 1985b).

The study of actual cases of regime formation suggests that these distinctions are best thought of as analytic rather than concrete in character. What this means is that specific instances of regime formation are apt to exhibit elements of all three processes, though one or another may be particularly prominent in individual cases. As those who have analyzed tacit bargaining have made clear, for example, successful negotiations regularly involve some convergence of expectations that cannot be explained through a study of the explicit bargaining process (Schelling, 1960; Axelrod, 1984; Downs and Rocke, 1990). Similarly, studies of bargaining strength have produced a rich set of observations about factors governing success or failure on the part of powerful actors seeking to bring their structural resources to bear on the process of regime formation (Young, 1994). The fact that the terms of international regimes are generally articulated in formal agreements, therefore, should not lead us to overlook self-generation and imposition as important aspects of the process of regime formation. The challenge before us at this point is to improve our grasp of the interactions among these processes as they play out in specific cases.

\subsection{Stages of Regime Formation}

Recent work has made it clear that it is useful to divide the process of regime formation into at least three stages: agenda formation, institutional choice and operationalization. The stage of agenda formation encompasses the emergence of an issue on the political agenda, the framing of the issue for consideration in international forums and the rise of the issue to a high enough place on the international agenda to warrant priority treatment (Stein, 1989). Institutional choice takes an issue from the point where it becomes a priority item on the international agenda to the point of agreement on the provisions of a specific regime. Operationalization covers all those activities required to transform an agreement on paper into a functioning social practice (Jacobson and Weiss, 1990). In international society, the operationalization stage often involves efforts on the part of member states to bring a regime's rules to bear on various non-state actors (e.g. fishers, oil tanker owners/operators, power plant managers) operating under their jurisdiction; it may also stimulate efforts on the part of those expecting their interests to be adversely affected by the operation of the regime to redefine some of its provisions. In some cases (e.g. the whaling regime or the vessel-source oil pollution regime), operationalization involves setting up international organizations to take charge of implementation review procedures, to make periodic decisions about the operation of the 
regime, to handle financial matters and to deal with various administrative issues.

It appears, at this point, that the relevance of the different processes of regime formation varies from one of these stages to another. Again and again, issues requiring the creation of international regimes are defined and developed conceptually in the absence of any explicit process. As the recent shift from single-species perspectives to whole ecosystems thinking suggests, this phase of the process is apt to reflect broader developments in the intellectual capital available to deal with such concerns. Similarly, there are severe constraints on the usefulness of imposition as a means of compelling individual states to act vigorously during the operationalization stage of regime formation. As recent experiences with issues like transboundary air pollution and deforestation make clear, in fact, powerful states sometimes find that they can make more progress through measures to build capacity and otherwise assist weaker states in their efforts to implement the terms of international regimes than they can through threats or sanctions intended to force weaker states to comply with the terms of international regimes.

\subsection{Driving Social Forces}

Much of the energy of those interested in regime formation has gone into efforts to identify specific factors that play a causal role in the process of institutional development and to assess the relative importance of these factors in actual cases (Haggard and Simmons, 1987). Three clusters of factors have emerged as the primary claimants for the attention of those concerned with regime formation: power, knowledge and interests. Realists and many neorealists view agreements setting forth the terms of international regimes as reflections of the distribution of power in the material sense (Strange, 1983). Regimes can therefore be expected to change from time to time in the wake of shifts in the distribution of structural power in international society. Those who stress the role of ideas often treat knowledge as a form of power that is distinct from structural power. They emphasize the role of consensual knowledge and social learning in the processes giving rise to international regimes (E. Haas, 1990). In extreme cases, institutional arrangements may be expressions of hegemony in the Gramscian or ideational sense (Cox, 1983).

Analysts stressing the role of interests look to interactive decision-making and the search for solutions to collective-action problems as the motivating force underlying regime formation (Young, 1989a; Zürn, 1992). Basing their arguments on models of interactive decision-making, many regime analysts have focused on problem structures and interest constellations as determinants of success in efforts to solve collective-action problems. The 
game-theoretically inclined, for example, have drawn a distinction between coordination problems (for example, battle of the sexes) in which there are stable equilibria and collaboration problems (for instance, prisoner's dilemma or chicken) in which equilibria are either suboptimal or absent (Stein, 1983; Martin, 1992). Whereas incentives to cheat and, therefore, concerns about the development of compliance mechanisms constitute a central concern in dealing with collaboration problems, there is much less need to worry about such matters in coming to terms with coordination problems. Others have focused on measures of the severity or intensity of conflicts of interest among interactive decision-makers - the idea of a spectrum ranging from pure cooperation to pure or zero-sum conflict is popular in such analyses - and argued that the intensity of conflicts of interest or the 'malignness' of problems is an important determinant not only of success in efforts to create institutions but also of the effectiveness of institutions once they are in place (Wettestad and Andresen, 1991). It is important to distinguish, on this account, between types of conflicts such as conflicts about values, which are the most difficult to solve, and conflicts about absolutely assessed goods, which are relatively easy to solve (Rittberger and Zürn, 1990).

Empirical work on regime formation has produced a number of notable conclusions about the role of these clusters of factors. Recent studies have provided little support for the theory of hegemonic stability, which stresses the role of dominant states in the process of regime formation and which has loomed for some time as a central concern of those who focus on power factors (Keohane, 1984; Rittberger, 1990; Young and Osherenko, 1993). Yet this does not mean that the role of power more generally is unimportant in the process of regime formation. It is worth considering a variety of other power-based arguments, such as the idea that some rough parity among the participants is important, in moving beyond the increasingly sterile debate about hegemony. Research on the role of ideas has focused recently on arguments pertaining to social learning and to the role of epistemic communities, construed as transnational groups of scientists and policymakers who become carriers and transmitters of ways of thinking about international problems and their solutions (Haas, 1992). Studies of actual cases have made it clear that these arguments will require considerably more development in analytic terms before they can be properly tested as contributions to our understanding of regime formation. One line of work on interest-based arguments is now centered on the idea of institutional bargaining, a form of bargaining featuring efforts to arrive at consensus on the terms of institutional arrangements under conditions of imperfect information about the payoff possibility set (Young, 1989b). These studies stress the importance of integrative as well as distributive bargaining and 
suggest that the image of 'life on the Pareto frontier' (Krasner, 1991) is a misleading one, at least when it comes to regime formation. Stressing the creative role of institutional bargaining, this way of thinking raises questions about the arguments many observers have made concerning the significance of problem structure as determinants of regime formation (Rittberger, 1990).

\subsection{Cross-Cutting Factors}

Efforts to sort out the relative importance of power, knowledge and interests through an examination of actual cases have revealed the significance of two additional factors that cut across the three original clusters: individual leadership and context. Careful reconstructions of the creation stories of specific regimes regularly point to the roles prominent individuals play at critical junctures in the formation processes (Young and Osherenko, 1993). In this connection, it is helpful to distinguish three types of leadership that parallel the driving social forces described in the preceding paragraphs (Young, 1991a). Structural leaders are individuals who represent states and devise stratagems for bringing power in the material or structural sense to bear on processes of regime formation. Intellectual leaders, by contrast, develop and exploit ideas to shape the way issues are framed and to energize the occurrence of social learning during formation processes. For their part, entrepreneurial leaders endeavor to highlight the integrative aspect of institutional bargaining, to craft new options capable of producing consensus, and to broker deals that lead to closure on the terms of constitutional contracts. Different types of leadership are apt to loom large in one or another of the stages of regime formation. Whereas intellectual leadership is particularly prominent at the agenda formation stage, entrepreneurial leadership is more important at the stage of institutional choice. But in virtually every case of successful regime formation, one or more key individuals have provided leadership at crucial turning-points.

The process of creating international regimes does not occur in a vacuum. Rather, this process unfolds in a setting in which any number of other issues can intrude to promote or impede the creation process. The outbreak of World War I in 1914, for example, terminated efforts to craft an international regime for the Svalbard Archipelago for a period of six years and ushered in a political setting in which the regime finally created in 1920 was radically different from the proposals on the table in 1914 (Singh and Saguirian, 1993). The initiation of the Conference on Security and Cooperation in Europe (CSCE) process in the 1970s and the desire on the part of the Soviet Union to convey a spirit of cooperation in this connection, by contrast, provided the impetus to reach agreement on the terms of a 
number of institutional arrangements. These include the Geneva Convention of 1979 setting forth initial provisions of a regime for long-range transboundary air pollution (Soroos, 1993), an arrangement which has subsequently evolved into a complex institution with considerable impact on the behavior of some of its members (Levy, 1993a). Because they are not connected with processes of regime formation in any substantive sense, the role these contextual or idiosyncratic factors play in specific cases is difficult to anticipate. Yet they can have drastic effects on regime creation, a fact that means we must be on the lookout for them at all times.

\subsection{Multivariate Models}

The challenge before us now is to move beyond efforts to single out individual factors as the key to regime formation in international society (Young and Osherenko, 1993; Efinger et al., 1993). In part, this endeavor must involve a recognition of the role of equifinality in the formation of international regimes or, in other words, the existence of multiple tracks along which such processes can move toward the same end (or equivalent ends). It is no doubt true that there are cases in which a dominant state or a hegemon supplies institutional arrangements to the members of a privileged group as a kind of public good. But there are many cases in which regime formation takes the form of a bargaining process among actors or coalitions that are more nearly equals. Similarly, while integrative bargaining and social learning loom large in some cases, other cases appear to be better understood in terms of the striking of deals among actors possessing a clear sense of the contours of the payoff space or the negotiation set associated with the institutional options available to them. The importance of equifinality indicates that we should not be overly concerned with the search for necessary conditions for success in the process of regime formation, a search that is likely to prove frustrating and relatively fruitless. Yet there is nothing in this realization to prevent us from identifying a number of tracks that successful processes of regime formation can follow - such as provision on the part of a single dominant actor or action on the part of a $k$ group or small number of leading actors (Schelling, 1978) — and from spelling out the sorts of cases that are likely to proceed along each of these tracks.

Equally important is the need to acknowledge that the distinctions laid out in the preceding sections are analytic in character and that interaction effects between and among them are the rule rather than the exception. Institutional bargaining, for example, often leads to a recasting of the nature of the problem under consideration; efforts to operationalize the terms of constitutional contracts frequently trigger a reconsideration of provisions accepted at an earlier stage or a move to augment or extend the provisions 
set forth in an initial agreement. Knowledge can produce new technologies that alter the relative bargaining power of those engaged in processes of regime formation. Yet power in the material sense sometimes allows its possessors to maintain and even increase their access to superior knowledge. These subtleties should not be allowed to derail efforts to construct generalizations that can help us to identify patterns in complex processes of regime formation. But they do emphasize the value of careful efforts to reconstruct the creation stories of individual regimes through procedures like process tracing and thick description. The challenge before us in improving our understanding of regime formation, then, is to delve into the subtleties of these interaction effects as they unfold in individual cases, without losing track of the importance of identifying patterns that can sustain useful generalizations about the creation of international regimes.

\section{Do Regimes Make a Difference?}

Early regime analysis focused on identifying the conditions under which international regimes form. Not surprisingly, skeptics branded this an irrelevant exercise, since it failed to address the question of whether regimes matter, in other words, whether they are more than epiphenomenal in relation to underlying social forces. The neorealists, in particular, regard institutionalized cooperation as a reflection of the distribution of structural power, implying that specific regimes will be abandoned when the underlying power distribution changes or when institutional commitments become inconvenient to one or more powerful member states. On this account, it is wasteful at best to devote resources to the analysis of institutionalized cooperation in world politics. At worst, it may prove seriously misleading.

There are two ways to meet this challenge and, in the process, demonstrate that regimes do make a difference. We can show that once established, regimes display a persistence or robustness that cannot be explained fully in terms of the conditions under which they formed in the first place. In a sense, this is a negative proof of the importance of international institutions. The positive proof goes one step further and aims at pinpointing specific ways in which regimes make a difference. Although this second strategy is methodologically more complicated, it is of great practical relevance and has become the focus of much of the current research on international regimes (see Section 5 below). In this section, we report briefly on the research that established the idea that regimes are more than mere epiphenomena. 


\subsection{Changes in Power Distribution}

Many observers have cited the formation of the GATT regime to regulate international trade as a clear illustration of the dynamic emphasized by the theory of hegemonic stability. The United States, which was clearly the dominant state in economic terms during the 1940s, took the lead in building this fundamental element of the postwar world order. Since the 1970s, however, America's economic dominance has declined, and the Japanese and European economies have caught up. Yet the global economic crises of the late 1970s and the early 1990s did not destroy the GATT regime. There have been modifications and adaptations of the GATT rules as well as some discordant actions. But these economic crises have not triggered competitive devaluations or wholesale protectionism. Robert Keohane has used this finding of 'cooperation after hegemony' to probe the functions of existing regimes. These functions entail, above all, reductions in uncertainty and insecurity. Thus, regimes (1) stabilize mutual expectations regarding future behavior, (2) reduce transaction costs, (3) produce information otherwise not available or available only at high cost and (4) provide a frame of reference that ensures that the interaction repeats itself frequently enough to generate a long 'shadow of the future' (Keohane, 1984: Ch. 7). Given stable constellations of interests and distributions of capacity, international regimes improve the contractual environment and thus stabilize cooperation, even if the conditions under which the regime came into existence no longer hold. Whereas regime-building may be difficult, the maintenance of regimes may prove easier. Thus, 'the high costs of regime building help existing regimes to persist' (Lynn-Jones, 1988: 498-9).

\subsection{Changes in Overall Relations}

If international regimes for specific issue areas perform their prescribed functions, they are likely to persist even when confronted with a deterioration of overall relations among the participants. Since deteriorating overall relations raise uncertainty about the motivations and future behavior of other actors, cooperation in issue areas not governed by the presence of regimes is likely to vanish as a consequence of such changes. In issue areas featuring stable regimes, however, meeting such challenges should pose fewer problems. This hypothesis is clearly corroborated by evidence from the study of East-West regimes (Rittberger and Zürn, 1990). Regimes established before the deterioration of overall East-West relations between 1979 and 1984 proved robust. The Baltic environmental protection regime, for example, was not affected at all by the worsening of East-West relations; none of the meetings of the consultative committees was canceled and the 
general problem-solving approach espoused by the participants remained unchanged. Similarly, the rules for managing conflicts in the issue area of Berlin, which had been highly contested for almost 30 years, remained fully operational. The inter-German trade regime also displayed resilience in the face of deteriorating overall relations. Pertinent analyses of other issue areas in East-West relations involving modes of conflict management approximating what we call regimes yield similar results. Neither the nuclear non-proliferation regime nor the incidents-at-sea regime was seriously affected by the deterioration of East-West relations beginning in the late 1970s. This robustness of East-West regimes seems even more remarkable when we compare issue areas in which conflict management did not cross the threshold of regime formation. In the cases of working conditions of foreign journalists and confidence- and security-building measures in Europe, the period between 1979 and 1984 had unambiguously negative impacts.

\subsection{Inconvenient Commitments}

Some analysts have suggested that regime persistence is best demonstrated through close observation of their influence on the decisions of individual governments, especially in cases where compliance with regime rules seems inconvenient. Pursuing this idea, Harald Müller (1993b) studied the role of the anti-ballistic missile treaty, construed as a component of the strategic nuclear weapons control regime, in American decision-making regarding strategic defense and Soviet decision-making regarding the illegal construction of an early-warning radar system at Krasnoyarsk. In both cases, influential civilian or military agencies sought to implement policies that violated the provisions of the regime. In each case, the regime proved to be a critical resource for those opposed to these policies. Concern that noncompliance would endanger the regime mobilized the resistance of those who believed the maintenance of the regime to be in the national interest. In addition, Müller shows that the regime itself - through its connection with international and domestic laws as well as through the foreseeable effects of defection on a state's international reputation - served as an important barrier to non-compliance.

\subsection{Unsatisfying Outcomes}

Another type of challenge to the persistence of international regimes arises in cases of apparent failure to solve problems. Studies of the ozone regime, the Mediterranean Action Plan and the Baltic Sea regime have shown that the initial institutional response to the problem at hand was grossly inadequate. 
But in each case, the creation of the regime initiated an institutional dynamic leading to a progressive adaptation of regime rules based on new knowledge about the nature of the problem. These 'evolutionary' (List, 1991) or 'dynamic' (Gehring, 1994) processes did not evaporate in the face of evidence of poor performance. Rather, the regimes became increasingly effective and robust through a process of internally generated reform. In his study of the Mediterranean Action Plan, for example, Peter Haas (1990) provides a detailed account of the ways in which activities initiated by regimes give rise to such evolutionary processes.

Once established, then, international regimes often prove robust when confronted with challenges stemming from changes in the perceived benefits and costs of living up to commitments, the distribution of power among the participants, or the overall relationship of the parties. If a regime seems too weak as initially constituted to achieve its institutional goals, moreover, this may trigger a dynamic leading to a strengthening of the regime itself. This does not mean, of course, that international regimes are eternal. A fundamental transformation in the domestic political system of a major member state leading to far-reaching changes in that party's international interests, for example, can cause the failure of international institutions. Thus, Nazi Germany abandoned almost all the institutional commitments of the Weimar Republic in order to build new ones with the Axis powers and various states in Southeastern Europe. If some of the world's major economic powers were to embrace a strategy of economic autarky, this development would undoubtedly endanger today's GATT regime. ${ }^{12}$ Similarly, regimes may be unable to survive the disappearance of key members. None of the regimes regulating German-German relations, for example, remains in place today, and many regimes regulating East-West relations are in transition. ${ }^{13}$ We know far less about processes of regime decline or decay than about the factors governing persistence of regimes in the face of changing circumstances. Studies of regime decay, moreover, should prove rewarding not only as ends in themselves but also as sources of insights regarding regime persistence.

\section{Regime Consequences: Effectiveness}

How exactly do international institutions operate to help society manage international problems? How much of the variance in problem-solving at the international level can we reasonably attribute to the operation of institutional arrangements in contrast to other forces at work in international society? Although the last decade has witnessed a striking growth of interest in international regimes, we remain unable to frame convincing answers to these central questions. For the most part, the answers proposed by those 
possessing extensive knowledge of individual regimes have failed to generalize to other cases. At the same time, the efforts of those seeking to compare and contrast a variety of regimes in these terms have encountered a number of problems concerning the drawing of causal inferences. This section reviews the evidence accumulated so far concerning the consequences of regimes. We have organized this effort under the rubric of effectiveness, because this concept directs attention to the consequences of international institutions having the most direct connection to the outcomes deemed desirable by the actors who create them. Regimes can have consequences that do not fit under the heading of effectiveness; some of these are discussed in the following section.

\subsection{The Meaning of Effectiveness}

Broadly speaking, effectiveness has to do with the contributions institutions make to solving the problems that motivate actors to create them. On further examination, however, effectiveness emerges as an elusive concept construed quite differently by various analysts. The significance of these differences lies in the fact that each meaning requires analysts to make a different combination of difficult normative, scientific and historical judgments.

International regimes commonly emerge in response to particular problems - environmental deterioration, escalating tariffs, border conflicts. In the final analysis, therefore, effectiveness is a matter of the degree to which a regime ameliorates the problem that prompted its creation. Is environmental quality improving, are tariffs. falling, are border clashes declining? Yet this definition presents practical difficulties that are sometimes severe. The social systems that are the focus of international regimes are typically complicated and subject to complex fluctuations. It is therefore difficult, under the best of circumstances, to ascribe observed changes to the operation of specific international rules. This difficulty is compounded by the fact that most problems serious enough to justify the creation of an international regime motivate actors to pursue solutions through a variety of means, including some that do not involve the regime directly. What looks like an effective regime, in terms of problem-solving, therefore, may be only an irrelevant side-show. Accordingly, the concept of problem-solving, which is appealing in directing our attention to the substantive bottom line, can become the source of its own limitations because it is so hard to apply meaningfully.

Under the circumstances, it is not surprising that students of regimes have turned to a variety of other approaches to elucidating the meaning of effectiveness. A legal definition of effectiveness holds that the measure of 
success is the degree to which conflicts become regulated by the rule of law (commonly reflected in contractual obligations), and to the extent to which contractual obligations are met - substantive provisions are implemented, rules are complied with, policies are adopted, and so on. In contrast to problem-solving, this view provides a more straightforward approach to measurement. But this operational clarity comes at a price, both because this approach ignores non-contractual consequences of regimes and because implementation and compliance tell us little about problem-solving. A more applied or policy-oriented definition, which appeals to many economists as well as practitioners, focuses on well-defined goals and asks what policy adjustments will prove effective in attaining these goals. This leads to interesting debates about such matters as the relative efficiency of commandand-control regulations and tradable permits as means of achieving targets specified by a regime. But it does not provide a basis for generalizing about the overall causal significance of institutions in addressing international problems. For its part, a political definition conceives of the problems regimes confront as a function of specific constellations of actors, interests and interactive relationships; it directs attention to behavior and behavioral change. Effective regimes cause changes in the behavior of actors and in patterns of interactions among them in ways that contribute to management of targeted problems. The primary strength of this approach is its firm connection to the real world through its emphasis on observable behavior. Among its drawbacks, on the other hand, are a tendency to lose sight of the objectives regimes are established to achieve and to slight policy concerns.

What are the implications of these definitional complications? If every scholar insisted on the prior development of a logically concise and easily operationalized definition of effectiveness, little research would get done. If we collectively insisted on the development of a common definition, there would be none at all. At this stage, there is room for a number of research strategies, some of which employ different definitions of effectiveness. What is essential in this connection is to state definitions explicitly, so that differences in both analytical and empirical findings can be debated meaningfully instead of getting confused with mere terminological differences. In the process, we should learn whether the use of different definitions of effectiveness leads to substantial divergences in judgments regarding the level of effectiveness achieved by individual regimes. In the review that follows, therefore, we seek to include relevant bodies of evidence, regardless of the particular definitions of effectiveness they employ. 


\subsection{The Domain of Effectiveness}

We can differentiate regime consequences along at least three distinct dimensions: (1) direct vs. indirect effects, (2) internal vs. external effects and (3) positive vs. negative effects.

In essence, the question of whether a regime's effects are direct or indirect is a matter of the length of the causal chain connecting the regime to the behavior in question. Direct effects are linked by short causal chains, indirect effects by longer ones. Generally speaking, it is easier to trace direct effects than indirect effects, although Miles (1989) found that many regimes produce greater effects through indirect means than direct means. Regimes commonly produce effects outside the issue areas that constitute their primary concerns. Such external effects can be caused by physical and biological linkages (e.g. when success in restoring one species leads to increased pressure on other species). They may also take the form of demonstration or other cognitive effects. Although the distinction between positive and negative effects is straightforward analytically, it requires difficult judgments in practice. What looks like progress to one analyst may represent a 'local maximum' that actually detracts from the achievement of an optimal solution. ${ }^{14}$ Though there are exceptions, most research on the effectiveness of international regimes focuses on direct and positive effects within a given issue area.

\subsection{Causal Bases of Effectiveness}

All the definitions of effectiveness imply some causal connection between the institution and the relevant behavioral changes. As Jørgen Wettestad and Steinar Andresen (1991) have pointed out, the real measure of a regime's effectiveness involves a comparison with what would have happened if the regime had never existed. This requires a demonstration of the causal links between the operation of the institution and the behavior of the relevant actors. ${ }^{15}$ A regime that fares poorly in terms of simple before-and-after comparisons may look more successful when causal links and counterfactuals are taken into account. GATT, for example, may seem relatively ineffective if we look only at the slow progress toward the removal of nontariff barriers over the past 20-years. Yet it appears considerably more effective when we ask what the pattern of international trade would have been during that period without GATT.

Scholars have employed a number of analytical techniques to sort out the true effects of international regimes from mere correlations that do not reflect causal links. We can group these techniques, which should be treated as a set of tools to be used in conjunction with one another, into two broad 
categories: natural experiments and thought experiments (Levy and Young, 1993).

The facts that we cannot conduct laboratory experiments involving international regimes and that the number of truly comparable cases is normally too small to allow for the use of standard statistical procedures clearly put us at a disadvantage in efforts to measure effectiveness. We face a problem much like that confronting those who seek to understand major episodes of biological extinctions or significant changes in the earth's climate system. But as these comparisons suggest, there are techniques of analysis that can help us to deal with this problem. We can make use of natural or quasi-experiments (Campbell and Stanley, 1966) by exploring comparisons across different issues areas or over time within a single evolving regime in such a way as to take advantage of variation on the independent variable. This involves examining situations that are comparable except for the presence or absence of a regime (or particular type of regime) or situations that remain largely unchanged over time except for alterations in the character of the prevailing regime. The case of oil pollution before and after the introduction of equipment standards (Mitchell, 1994b) is a case in point. If the two distinct institutional configurations correspond closely with observable differences in outcomes, we can infer that there is a good chance that these differences are attributable to the institutional variable. Given the nature of such experiments, it is important not to overestimate the significance of the inferences drawn. Observed differences in outcomes may well be results of concomitant but unnoticed variations across our cases in factors other than the institutional variable. Nonetheless, this is an exercise well worth pursuing as one means of separating institutional effects from the causal forces invoked in various rival hypotheses.

To complement the findings derivable from natural experiments, we can also make use of thought experiments. Specifically, students of regimes have turned to what has become known in the recent international relations literature as the method of counter-factuals (Fearon, 1991; Biersteker, 1993). In effect, this technique involves a rigorous effort to recontruct the flow of events as it would have unfolded in the absence of some key factor (e.g. the introduction of a particular regime or social practice) and to compare the results with the actual flow of events. What would have happened, for example, if those responsible for the oil pollution regime had not shifted from discharge standards to equipment standards? Similarly, how would the problem of transboundary air pollution in Europe have evolved if the players had not seized the opportunity afforded by the initiation of the CSCE process and the lull in the Cold War to reach agreement on the terms of the Geneva Convention of 1979? Clearly, this sort of analysis can become sloppy and lose its value in the hands of careless analysts. The keys to success 
in such endeavors involve framing counter-factuals as precisely as possible and delving deeply into behavior of key actors at critical junctures. This means looking at decision-making processes within regime members, focusing on important branching points where events might have taken a different course, and asking what path would have been followed if the regime had not existed. Terms like process tracing and thick description (Geertz, 1973) are often used to characterize this method of probing the causal links between regimes and their effects.

Although no single procedure can be expected to yield definitive proof, applying this set of analytical techniques to a growing collection of international regimes offers the prospect of building up an increasingly well-defined picture of the role of institutions as determinants of collective outcomes in international society. This effort is unlikely to yield dramatic conclusions to the effect that institutions are always critical determinants of outcomes or, conversely, that institutions never matter. Rather, we can expect to move toward more realistic and interesting conclusions by identifying conditions that determine when regimes matter and the extent to which these arrangements matter in a variety of social settings that are typical of international society.

\subsection{Review of Hypotheses and Evidence ${ }^{16}$}

We turn now to an appraisal of the state of empirical knowledge about what makes international regimes more or less effective. This involves a review of three bodies of literature: (1) work emphasizing exogenous factors or factors external to institutions, (2) work looking to endogenous or internal sources of effectiveness and (3) work seeking to identify behavioral mechanisms linking institutional characteristics with collective outcomes.

Exogenous Factor. Much of the scholarly interest in regime effectiveness has focused on exogenous factors. In this account, we separate out the following clusters of factors; the pattern of interests in the relevant issue area, the distribution of influence among the participants and the role of structural constraints (e.g. the capacity to monitor behavior, the state of scientific knowledge or the occurrence of shocks and crises).

Patterns of Interests: The behavioral changes international regimes seek to promote almost always have negative consequences for some sets of interests: power plants are asked to install sulfur dioxide scrubbers to reduce acid rain, protected manufacturers have to compete with lower tariffs. It is possible that some interests will be positively affected as well. Owners of commercial timber stocks will benefit from reductions in acid rain; consumers and exporters benefit from lower tariffs. 
The configuration of negatively and positively affected interests constrains the ability of international institutions to affect behavior. Many accounts of the early phases of the European acid rain case, for example, stressed the distribution of interests as imposing an overwhelming constraint on the ability of the Convention on Long-Range Transboundary Air Pollution (LRTAP) to bring about behavioral changes. A few low-pollution states suffered the bulk of the damage from acid rain, whereas high-pollution states either suffered little damage (e.g. Britain) or had no interest in preventing such damage (e.g. Poland, Czechoslovakia, East Germany). Even though this factor has received sustained attention in the analysis of regime formation, however, it has lurked in the shadows of the effectiveness debate (Kay and Jacobson, 1983). Nonetheless, in case studies of the effectiveness of individual regimes, the distribution of interests consistently emerges as an important factor.

Distribution of Influence: Another line of inquiry examines how the distribution of influence among the participants affects the ability of an institution to succeed at its task. There are debates over what types of distribution and what types of influence promote effectiveness. As with the claims made about the impact of interests, most discussions of this factor have taken the form of ad hoc claims made with respect to specific institutions; there has been less sustained effort aimed at uncovering general causal relationships.

The distribution of coercive power appears to affect an institution's ability to bring about behavioral changes. American fishing quotas in its exclusive economic zone provided a power resource used to promote compliance with International Whaling Commission (IWC) quotas (Andresen, 1989; Peterson, 1992). American oil imports, combined with a threat to impose unilateral regulations on tankers entering its ports, gave the United States influence that led to tightening MARPOL (International Convention for the Prevention of Pollution from Ships) standards (M'Gonigle and Zacher, 1979). Clearly, coercive power by itself is no guarantee of success; it must be concentrated among proponents of institutional objectives. According to one strand of hegemonic stability theory, a concentration of coercive power in a state that supports institutional goals is virtually a necessary condition for institutional success (Gilpin, 1987). This conclusion is based on the argument that in situations characterized by mixed motives (in which actors have an interest in collective restraint but also would like to shirk and let others bear the burden), an enforcer is required to prevent 'free-riding'. Another strand of theorizing also concludes that a concentration of influence is required for institutions to be effective, but focuses on less coercive forms of influence. Accordingly, individual leadership is a necessary condition for institutional success (Young and Osherenko, 1993). Such 
leadership might take the form of political entrepreneurship or intellectual persuasion as well as efforts to bring structural power to bear on a problem. The conclusion that leadership is necessary is based in part on the deductive argument that institutional success requires a cementing of complex bargains that states, left to their own devices, will be unable to realize. It is based also on empirical work that every successful case of regime creation studied in the project featured a pivotal role for leadership.

Peter Haas has focused attention on one particular form of non-coercive influence featuring the role of 'epistemic communities'. In a comparative study of efforts to protect regional seas, which builds on his study of the Mediterranean Action Plan, Haas (1992) finds that the following conditions have prevailed in most successful regional seas efforts: (1) the presence of a regional community of able marine scientists interested in environmental management, (2) 'Respect by political decision makers for the authority and expertise of these scientists' and (3) the existence of channels of contact or influence between the scientific community and national policy-makers.

A related argument points to the distribution of capacity as a factor effecting the success of regimes. Some institutions seek adjustment on the part of actors who simply lack the capacity to make the necessary changes. States with weak administrative and legal institutions often cannot comply with an institution's directives, even when they have an interest in doing so. Institutions with large numbers of low-capacity states as members will tend to fail more often than institutions seeking to influence the behavior of highcapacity states. Monetary agreements often break down, for example, when they require actions that are beyond the capacity of central banks. Putnam's (1988) 'involuntary defection' constitutes a clear example of capacity-driven failure.

Nature of the Issue Area: Finally, some institutions may do better than others because they operate in a relatively benign issue area. Some international problems, for example, are marked by unambiguous shocks and crises; others sneak up on relevant actors and do not galvanize them into action until it is too late. The case of regulating oil tankers reveals what can happen when lots of shocks and crises occur. Successful regulatory action began as early as 1954, following massive oil slicks on British beaches; a series of tanker accidents since then has helped maintain pressure that has been translated into a steady tightening of rules governing safety and operational standards of tankers. It is hard to imagine MARPOL evolving in this direction in the absence of these high-visibility shocks. The publicization of Waldsterben in 1981-2 and the ozone hole in 1985-6 also appear to have boosted the effectiveness of the regimes established to deal with acid rain and ozone depletion. Other problems do not provide such early warnings, and institutions designed to address them have encountered greater barriers 
Marc A. Levy et al.

to success. This is arguably the case with regard to most fisheries: time-lags often delay the emergence of crises until stocks have been drawn down so low that no effective institutional responses are available. A similar situation may explain the limited success of attempts to cope with the LDC debt crisis; the crisis became apparent to policy-makers after the problem had become highly intractable.

Another factor that can influence effectiveness is the ability to monitor the behavior of relevant actors. Where such ability is high, actors will be more willing to engage in mutual self-restraint, knowing that they will be able to detect violations on the part of others and respond accordingly. Where monitoring is difficult or impossible, by contrast, actors will worry that they will be unable to detect violations and therefore be less willing to undertake measures due to a fear of being cheated. In such cases, actors willing to bring pressure to bear on violators will be unable to determine who deserves their wrath. Monitoring of international fisheries, for example, is especially problematic due to the highly fragmented nature of the industry and the fact that most actual harvesting occurs far out of sight. This may be an important factor in explaining why few fisheries regimes have succeeded in preserving the relevant stocks.

Concluding Thoughts on Exogenous Factors: Scholars who emphasize exogenous factors as sources of institutional effectiveness must address a fundamental objection: if the exogenous forces seem so influential, how can we attribute a causal role to the institution? Many analysts fail to confront this question directly, and their claims suffer as a result. In theory, there is nothing incompatible with strong influence from exogenous forces and a positive role for institutions. Consider, for example, the effectiveness of postWorld War II economic arrangements as compared to the abortive attempts of the 1920s. Many accounts stress the greater interest in cooperation in the postwar period as the key factor. But this does not mean that the Bretton Woods institutions were unimportant. If an institution performs important functions that could not have been handled in its absence, then changed interests are insufficient to explain greater cooperation. Yet most treatments of cooperation that stress exogenous factors treat the relationship between exogenous factors and the roles institutions play sloppily, blurring the distinction between exogenous causes of behavior and exogenous constraints on the ability of institutions to influence behavior. Haas's list of exogenous 'preconditions' for effective regional seas regimes, for example, is the same as his list of UNEP's institutional objectives, a fact that makes it impossible to distinguish cases in which the institution made a difference from those in which it merely allowed external events to take their course. One way to avoid this pitfall is to present explicit causal arguments, specifying exactly what the initial conditions are, what the institutional 
response and exogenous forces are, and how these factors interact causally to produce the observed outcome. ${ }^{17}$

Endogenous Factors. The search for endogenous sources of effectiveness is based on the premise that there are good and bad ways of structuring international institutions as well as good and bad ways of administering these arrangements operationally. Getting the rules right, engaging energetic and creative secretariats, and initiating the right kinds of programmatic activities may be important determinants of effectiveness. Analytically, this means that we may be able to explain variation in institutional effectiveness in terms of variation in these endogenous features. All such efforts must tackle an ageold source of criticism. It is possible that variation in endogenous features is perfectly correlated with variation in interests and power capabilities, so that these endogenous factors themselves carry no independent explanatory weight. Some institutions may be 'designed to fail' by actors who covertly want them to fail (Moe, 1991); others may be blessed with effective design features because powerful actors want them to succeed. In either case, the most persuasive explanation lies in the interests and power capabilities of the relevant actors; the endogenous features are derivative. One way to avoid this pitfall is to control for relevant exogenous variables before seeking differences in outcomes that correlate with differences in endogenous variables. These methodological problems notwithstanding, a number of analysts have formulated propositions about institutional effectiveness featuring factors endogenous to international regimes. In this account, we divide these into propositions concerning design features of international regimes and propositions about programmatic activities of regimes.

Design Features: The view that an institution's origins shape its destiny is as old as politics itself. Ever since practitioners and theorists began arguing about proper forms of constitutions, they have acted on the premise that the design features embedded in political institutions affect the ability of those institutions to carry out the tasks assigned to them. From Plato's ruminations on the best way to organize a city-state in order to make justice flourish, to Rousseau's ideas on what sorts of political organizations make freedom possible, to Madison's thoughts on how federal constitutions can prevent tyranny, and right on to recent debates over how to reform the European Union's institutions, we see a clear concern with institutional design features as important sources of effectiveness.

Among recent students of institutions, Elinor Ostrom (1990) has most consistently and rigorously addressed questions of institutional design, though she has only recently turned her attention to international issues. McGinnis and Ostrom (1992) provide a set of 'design principles' that they claim contribute to the effectiveness of international institutions for the 
Marc A. Levy et al.

management of common-pool resources. These principles point to factors endogenous to the institutions 'that help to account for the success of these institutions in sustaining the [common pool resources] and gaining the compliance of generation after generation of participants' (McGinnis and Ostrom, 1992: 2). The specific design principles McGinnis and Ostrom propose are derived from a long-term study of domestic institutions established to manage common pool resources; these authors give plausible reasons for presuming that lessons drawn from a study of domestic institutions will prove relevant to international regimes, though they do not subject this view to the same level of rigorous testing that Ostrom has carried out for domestic institutions. The basis of their conclusions is therefore a mixture of rigorous testing (at the level of propositiongeneration) and theoretical conjecture (at the level of proposition-testing). McGinnis and Ostrom summarize their principles for institutional success as follows:

- Rights to utilize resources are clearly defined, as are the boundaries of the resource in question.

- Rules match local circumstances.

- Individuals affected by operational rules have an opportunity to participate in modifying the rules.

- Monitoring of resource health and participant behavior is conducted by agents accountable to the participants.

- Violators are subject to graduated sanctions.

- Participants have access to low-cost arenas of conflict resolution.

- The rights of participants to devise their own institutions are not challenged by other authorities.

- Institutional activity is organized in multiple, nested layers.

Few, if any, of these design principles have been explored systematically across a range of international regimes; they remain hypotheses in need of testing. An empirical study recently completed by Abram Chayes and Antonia Chayes $(1993,1995)$ reports interim results that confirm these ideas only partially. Chayes and Chayes support the importance of the first principle, concluding that many cases of non-compliance stem from 'ambiguity and indeterminacy of treaty language' (Chayes and Chayes, 1993: 188-9). However, they find that international institutions virtually never utilize sanctions to achieve their goals. Conflict resolution mechanisms are sometimes important sources of compliance, they find, but in many cases they amount to boilerplate arrangements with little political effect.

Other analysts have produced independent assessments of design features. Ronald Mitchell (1994a) examines efforts to reduce operational discharges of oil from tankers and reaches several conclusions about ways in which 
endogenous features of international institutions shape their effectiveness. He finds, for example, that rules aimed at ship builders have been more effective than rules aimed at ship operators, and he draws the general lesson that rules are more effective when they target actors who have the greatest incentive to comply. (In a sense, this is a specific manifestation of the second principle of McGinnis and Ostrom.)

Peter Sand (1990) has formulated yet another set of design options, which he claims promote effective institutional responses to environmental problems. These include:

- Allowing for interim operation, before entry-into-force.

- Utilizing soft-law to promote action when binding rules are politically impossible.

- Delegating decision-making power to a specialized body.

- Setting standards at a regional rather than the global level.

- Providing selective incentives, including technology and finances.

- Setting differential obligations, rather than common standards (see also Parson and Zeckhauser, forthcoming).

- Conducting regular reviews of institutional performance (also see Lee, 1993).

Sand offers trenchant illustrations for each of his propositions. From the perspective of political science, however, they also remain hypotheses in need of testing rather than empirically tested propositions. They require analysis involving behavior rather than law, and this means detailed case studies including some comparative studies of cases in which institutions with such provisions are compared to regimes without them.

The need to focus on behavior is critical, because we must ultimately change the behavior of actors to solve international problems. It is possible that wily political actors will respond to improved legal rules with evasive behavioral action, leaving the underlying problem unsolved. The International Maritime Organization (IMO), for example, adopted in 1973 a change in rules governing amendments to MARPOL that took effect in 1983. Rather than requiring formal ratification in each case, amendments now enter into force automatically after 16 months, unless more than onethird of the parties representing more than $50 \%$ of world shipping tonnage issue objections. This has had the effect of generating improved law: amendments enter into force quickly, rather than suffering from the problem of being held hostage for years to states that withhold ratification - often amendments would not enter into force until after they were made obsolete by newer amendments (Mitchell, 1993). Yet it is not clear that this has had any effect at all on state behavior. A comparison of amendments to MARPOL before and after the changed entry-into-force procedure suggests 
Marc A. Levy et al.

that states have responded to the new procedure by passing nothing but very weak amendments (Underdal, 1992).

A number of authors interested in effectiveness have emphasized the importance of the ways in which scientific and technical advice is institutionalized. Edward A. Parson has found that the design of the Montreal Protocol's scientific and technical committees fostered the development of productive scientific consensus and creative problem-solving, and lowered political posturing. Specifically, the constitution of these bodies as nongovernmental entities has helped ensure that only qualified experts serve and that they do so in the name of their disciplines rather than their governments (Parson, 1993). Other studies emphasizing the organization of scientific advice in determining the effectiveness of institutional arrangements include works by Ernst Haas (1990), Peter Haas (1989) and Edward Miles (1989). All these analysts argue that effective institutional responses require organizational designs giving agenda-setting power to individuals who share a common, scientific approach to knowledge and problem-solving. Boehmer-Christiansen (1989), on the other hand, offers a more skeptical view on this topic.

Programmatic Activities: To be effective institutions may require not only the right beginnings, but also a well-constructed set of programmatic activities. Kay and Jacobson (1983: 'Conclusion') list a number of operational factors that contribute to organizational success: recognizing and nurturing competence, emergence of dynamic leadership, ability to perform basic organizational tasks (e.g. typing, translation) and imagination and creativity. All of these are factors endogenous to institutions yet not determined by their constitution. They reflect the choices actors make and the actions they take within the framework of existing institutions.

Mitchell has found that compliance with reporting requirements improves greatly when secretariats submit questionnaires prompting specific government officials to provide the required information (Mitchell, 1994a). More generally, some secretariats take on political roles, seeking to embarrass or cajole laggards, while others prefer to stay out of the picture and let the parties fight their political battles on their own. It is not clear which of these strategies is most effective, and the answer may well depend on the nature of the circumstances.

Some observers have pointed to flexibility or adaptability as a source of effectiveness. (Flexibility might be considered a matter of design as well as an operational issue; its inclusion in this section is not meant to indicate otherwise.) Thus, GATT's flexibility is often pointed to as one of the sources of its effectiveness. Chayes and Chayes argue more generally that compliance with the terms of regulative treaties improves when they are administered in a flexible manner, allowing some leeway for 'acceptable' levels of noncompliance. It is worth pointing out as well that an element of what might 
be called 'professionalism' (i.e. the absence of cronyism, patronage and corruption; rewarding performance according to merit, etc.) probably makes for more effective regimes. Some regimes get captured by ambitious, selfserving bureaucrats, while others - perhaps because their budgets make them small prizes - remain in the hands of professionals.

Concluding Thoughts on Endogenous Factors: The endogenous factors contributing to the effectiveness of international institutions have been subjected to less rigorous testing than the exogenous factors. Political scientists have tended, to date, to extend ongoing debates about International Relations more generally into the study of regimes. It so happens that at the time political scientists became interested in international regimes most of these debates centered on exogenous factors (mainly pertaining to power and interests). If research on regimes had blossomed 80 years ago, prevailing theoretical debates would probably have focused more attention on endogenous factors. As a result, there has been a divide between those applying rigorous, scientific methods to questions of limited practical utility, and those asking politically important questions but employing much less reliable methods in determining the answers. In the succeeding paragraphs, we discuss one strategy for overcoming this problem.

Behavioral Mechanisms. When international regimes operate effectively, they make use of endogenous facts (rules, procedures, programs) to alter exogenous facts (patterns of influence and interest, behavior of actors). An understanding of the phenomenon of effectiveness therefore requires analysis at both levels; attempts to discover pieces of the puzzle exclusively within one level or the other are bound to yield inconclusive results. What we need in order to understand effectiveness, then, are studies of how the design features and programmatic activities of institutions interact with the configurations of interests and patterns of influence within which they operate. Isolated case studies do exist, but we have not yet made much progress toward cumulative knowledge in the area that will prove useful to both theorists and practitioners.

One promising approach that has surfaced recently in the study of international regimes is to focus attention on behavioral mechanisms highlighting specific causal links between institutional facts and behavioral outcomes. Such an effort does not replace work aimed at deepening our understanding of exogenous and endogenous forces determining effectiveness. Instead, it can help us make more sense of the overall phenomenon by providing a non-arbitrary way to link knowledge of the two levels.

It can be argued that international environmental regimes achieve effectiveness by carrying out three central tasks (Haas et al., 1993: 'Conclusion'): increasing concern, improving the contractual environment 
and increasing the capacity of governments. These mechanisms - the three Cs - link institutions with their external environment. The appropriate mixture of institutional strategies depends on the state of the political environment in which an institution is located. Low levels of concern, poor contractual environments and weak capacity are each sufficient to cause failures in collective management of environmental risks. Therefore, where any of these conditions prevails, institutions must intervene to ameliorate them in order to achieve their goals. When concern and capacity are high, an institution needs only augment the ability of members to make and keep contracts to succeed. This may have been the case with regard to postwar trade cooperation among advanced industrial states. If concern is also lacking, institutions must engage in activities that boost concern. The acid rain regime in Europe succeeded in doing this, in part by creating scientific working groups and providing forums to embarrass laggards. The nuclear non-proliferation regime tries to do this by imposing sanctions on violators. Where capacity is also weak, institutions must operate to augment capacity in order to be effective. The IMF seeks to do this by helping governments reform policies and domestic institutions.

The contributors to the volume edited by Haas et al. (1993) discovered the significance of these causal mechanisms more or less inductively, through an effort to develop and interpret seven case studies. But there is a clear need for a more systematic examination of behavioral mechanisms. An alternative classification of behavioral mechanisms underlies the Dartmouth-based project on effectiveness currently nearing completion. These mechanisms, specified deductively and subsequently elaborated through empirical investigations, are summarized in the succeeding paragraphs (Levy and Young, 1994).

Regimes as Utility Modifiers: The causal mechanism underlying this model draws on the tradition that views actors as self-interested utility maximizers. It posits that actors' behavior can be guided by institutional arrangements to the extent that they alter the costs and benefits individual actors attach to well-defined options. Actors change their behavior if and when the rules of the game make it worth their while to do so. The essential logic is one of linkage. Regimes modify utility calculations by linking issues that were otherwise not linked. They threaten penalties for non-compliance, for example, or they promise rewards for compliance.

Regimes as Enhancers of Cooperation: Although this model also rests on utilitarian premises, it is helpful to separate it out for individual treatment because it directs attention to the collective-action problems which are widely viewed among students of International Relations as important obstacles to the achievement of sustained cooperation. The essential point is that there are many circumstances under which rational actors engaged in interactive decision-making fail to avoid joint losses or reap joint gains due 
to the effects of strategic behavior. Regimes, on this account, emerge as mechanisms for alleviating these problems and allowing the participants to achieve collective outcomes that lie closer to the Pareto frontier. Because collective-action problems take a variety of forms, regimes created to alleviate these problems can affect behavior in a number of ways. They may, for example, serve to mitigate fears of cheating through measures designed to increase the transparency of the behavior of relevant actors. They may reduce incentives to defect either by calling sanctions down upon violators or by lengthening the shadow of the future with regard to the issues in question. Or they may simply reduce transaction costs by making it unnecessary to cope with the consequences of strategic behavior again and again in the same issue area. But the basic point remains the same: In this model, regimes affect behavior by mitigating the collective-action problems that stand as barriers to the avoidance of joint losses or the realization of joint gains otherwise available to parties engaged in interactive decisionmaking. Much of the recent literature on international regimes has proceeded on the assumption that this is their principal function.

Regimes as Bestowers of Authority: The basic premise of this model is that the behavior of states and non-state actors alike is often rooted in a respect for authority, rather than in some sort of utilitarian calculus concerning the benefits and costs of options available to them. In the case of individuals, this is apt to be a consequence of socialization. Most people are taught to act in certain ways because it is the right and proper thing to do or because it is the law, rather than because it is in their self-interest to do so. In general, people are most likely to respond in this way when they feel that the authority in question is legitimate and deserving of their respect. Those who have escaped the grip of the resultant 'habit of obedience' (Hart, 1961) and who routinely question authority are the exceptions in most social settings. When we come to collective entities, on the other hand, the behavior this model points to is apt to be as much a consequence of routinization as of socialization. More often than not, agencies charged with the implementation of regimes come to treat the fulfillment of this goal as part of their organizational mission to be pursued without constant questioning of the social consequences flowing from the rules in question and defended in dealings with other agencies pursuing their own missions. In both cases, however, it is the authoritativeness of regime rules and activities that triggers the behavioral response rather than some calculation of the anticipated benefits and costs associated with different options available to decision-makers. Those who think in utilitarian, much less realist or neorealist, terms may find it hard to believe that behavior of this sort is prevalent at the international level, whatever its status in domestic society. But it would be a mistake to rule out this source of behavior in examining 
the behavioral mechanisms that give rise to the effects of international regimes.

Regimes as Learning Facilitators: Institutions, in this model, achieve their effects by initiating processes that give rise to individual and social learning. The learning in question can take the form of new perspectives on the nature of a problem to be solved, new ideas about measures likely to prove effective in solving the problem, or new insights into the process of implementing these measures. The route to such learning may lead either through the generation of new facts that reduce uncertainty or produce a more accurate picture of the issues at stake or through the reassessment of values and a resultant redefinition of actor interests (Nye, 1987). The evidence suggests, for example, that the LRTAP regime has played a role not only in enhancing our understanding of the mechanisms at work in long-range air pollution but also in energizing a broader process of consciousness-raising regarding the importance of the impacts of air pollution on human health and natural systems. The actual processes through which learning occurs are not well understood. Thus, we need to improve our grasp of the roles of individual leaders, communities of scientists and epistemic communities in the learning process. But the essential point of this model is clear enough. It spotlights the roles that regimes play in changing information and values and, in the process, altering the incentives and interests that shape the behavior of individuals and collective entities active in the issue areas covered by the regimes.

Regimes as Role Definers: Yet another behavioral model emphasizes the fact that regimes sometimes operate at the constitutive level, shaping the identity (and therefore the interests) of actors and, in the process, influencing the way actors behave as occupants of the roles to which they are assigned. Most of us are accustomed to forms of contractarianism that treat actors and their interests as given and proceed to analyze the bargaining processes through which such actors endeavor to hammer out the terms of social contracts. But it is perfectly possible to turn this analysis on its head and look at the ways in which institutions operate to define and assign roles. In fact, actors regularly take on new roles under the terms of institutional arrangements, even when their basic identities are well established prior to the emergence of the rules in question. Consider the striking changes in the roles of flag, coastal and port states under the new law of the sea and, more specifically, the rules relating to exclusive economic zones and marine pollution as cases in point. The enhanced role of coastal states certainly helped Norway and Russia to phase out third-party fishing in the Barents Sea, and the growing strength of coastal and port states in relation to flag states appears to be a factor of some significance in the case of oil pollution. Of course, the redefinition of old roles or the creation of new roles may in 
turn reflect the evolution of underlying ideas regarding relevant issues. But the key point here is that the causal mechanism associated with this model directs our attention to sources of behavior that lie behind or beneath the sorts of factors identified in utilitarian arguments.

Regimes as Agents of Internal Realignments: What distinguishes this model from the others is its emphasis on the proposition that both the members of international regimes and others active in the relevant behavioral complexes need not be treated as unitary actors. Regimes, on this account, affect behavior by creating new constituencies or shifting the balance among factions or subgroups vying for influence within individual actors. In the simplest cases, the establishment of a regime gives some of those involved in an issue area new ammunition in their dealings with others. The East-West Helsinki Accord, for instance, may have bolstered American human rights advocates in their battles with proponents of detente. Beyond this, regimes can actually play some role in restructuring the alignment of domestic groups endeavoring to influence a government's behavior or factions seeking to redirect a corporation's behavior. GATT may have played such a role in breaking the longstanding regional and party divisions on tariff issues that formerly dominated American politics.

\subsection{Conclusions on Effectiveness}

Analysis regarding the mechanisms through which regimes succeed or fail has been overshadowed by debates over whether international institutions matter at all and by efforts to explain their creation. Because the regime creation literature has reached a degree of maturity (see Section 3), and because we now know that determining whether regimes matter requires us to demonstrate how they matter, much more attention is being directed at this juncture to questions of effectiveness. Promising work has been carried out on exogenous and endogenous sources of effectiveness. Improving our understanding of the overall phenomenon, however, will require nonarbitrary ways to link the two sets of factors. The analysis of behavioral mechanisms is one promising vehicle for doing so.

The three Cs (Haas et al., 1993) and the six behavioral mechanisms (Levy and Young, 1994) are two complementary models for elaborating causal pathways. The three Cs, for their part, are each quite broad, encompassing a wide range of specific mechanisms. The single category 'concern', for example, touches on all but one of the six Dartmouth mechanisms (enhancers of cooperation). Many of the Dartmouth mechanisms also pertain to each of the three Cs. 'Utility modification', for example, can play a role in raising concern, building capacity or enhancing the contractual environment. This high degree of complementary overlap suggests the 
possibility of a two-dimensional map of behavioral mechanisms. Although it is not clear whether devising such a two-dimensional map would be the most productive line of future elaboration, it is clear that more work along these lines is called for.

\section{Regime Consequences: Broader Effects}

All approaches to assessing the effectiveness of regimes share an interest in determining the extent to which institutions affect outputs, outcomes and impacts in the issue areas these arrangements address. But in the real world, issue areas are not neatly separated. Developments in one issue area often have substantial consequences for other issue areas. Some ecologists, for instance, claim that the recently concluded Uruguay Round of GATT negotiations will have serious adverse consequences for the global environment. As this example suggests, most consequences external to an issue area - whether positive or negative - are not intended by those who design regimes producing such effects. External consequences are products of a functionally differentiated society, the overall complexity of which is too great to allow policy-makers to foresee all effects of a given measure. Equally important, regimes focused on specific issues affect not only other issue areas but also the broader or deeper structure of international society as a whole. It is especially important to probe the links between international regimes and the underlying constitutive principles of international society (e.g. state sovereignty). Without an understanding of this relationship, the study of international governance remains truncated.

Analyzing the broader effects of international regimes, however, is difficult. In addition to the complications discussed in the preceding section on effectiveness, studies of broader effects have to overcome at least three other obstacles. In the first place, regime analysts devote a lot of effort to becoming specialists regarding the issue areas they study. Any single person will find it extremely difficult to maintain a level of information about other international issue areas that would allow for informed judgments about broader effects. Moreover, the range of possible broader effects of a given international regime is unlimited. Because regime analysis has not yet developed a well-defined method for the study of broader effects, a common dependent variable to be used in formulating generalizable statements is still missing in this field. What is more, one strand of social theory maintains that the process of functional differentiation in international society has reached a point where causal and interactive complexities make it impossible for policy-makers and analysts alike to comprehend the full range of broader effects arising from the operation of specific regimes.

Overall, the study of broader regime consequences is both an important 
and an especially difficult task for students of international institutions. This means that the study of broader effects will always contain an element of speculation. On a very general level, however, we may differentiate broader regime consequences on the basis of whether they affect states and interstate relations or international society and transnational relations. At each level, it is helpful to ask whether broader consequences affect actor capabilities, interests, cognitive matters or constitutive principles.

\subsection{States and Interstate Relations}

Regimes often redistribute issue-specific resources among their members. Yet actors can make use of some resources across issue areas or trade them for additional issue-specific resources. The renunciation of nuclear weapons by Germany and Japan in the nuclear non-proliferation regime, for instance, increased their dependence on American security resources. In the early 1970s, at least, the United States was able to utilize this situation to extract concessions in the economic sphere. With the exception of the work of Joseph Grieco (1990), who maintains that an unequal distribution of benefits from cooperation constitutes an insurmountable obstacle to regimebuilding in an anarchical society, little effort has been made so far to explore the broader consequences of regime impacts on the distribution of state capacities.

Recent studies have emphasized that regimes are not simply static complexes of rules and norms. They may also serve as important vehicles for individual and social learning. Of course, some learning features improvements in the understanding of governments about cause-effect relationships in a regime's issue area. But a broader type of learning occurs when a principle applicable to more than one issue area proves successful in specific cases. The idea of 'embedded liberalism', for example, arose in connection with international trade after World War II. But over time it became an influential principle in other economic issue areas as well (Ruggie, 1983; Burley, 1993). Similarly, broader effects may occur when a specific international regime plays a role in altering general perceptions of other actors. Confidence-building measures in East-West relations, for example, contributed to the development of a friendlier image of the Soviet Union in Western Europe (Rittberger et al., 1990). In addition to cognitive changes relating to cause-effect relationships and intentions ascribed to other actors, regimes may also affect value hierarchies and, as a result, the formulation of interests. Learning about the dangers of global warming as a result of the operation of the climate change regime, for instance, may lead to changes that go beyond mere 'adaptation' to a redefinition of the goals of policy (E. Haas, 1990). Such fundamental redefinitions would have effects reaching 
Marc A. Levy et al.

beyond the issue area of climate change, since climate change necessarily involves a host of economic issues.

With respect to constitutive concerns, neofunctionalists and other recent integration theorists emphasize that nation-building and international integration are much more results of generative processes than conscious decisions. For the most part, the issue of political integration arose when people demanded more adequate services of one kind or another from their governments. Integration was first considered as a possible means to further these ends rather than as an end in itself (Deutsch et al., 1957: 90). Thus, an increasing density of international regimes, all created for different purposes, may initiate a takeoff towards political integration. In this sense, the study of international regimes offers a micro-level approach to understanding the macro-level phenomenon of integration. Along the same lines, any given regime not only reflects an end toward which the norms and rules are directed, it also involves a procedure for regulating conflicts. When international regimes are seen as procedures for the regulation of conflict, it becomes plausible to think of these institutions as contributing to a civilizing process in international politics, in which the conduct of conflict is institutionalized and does not lead to a resort to violence (Rittberger and Zürn, 1990). Interestingly, both integration theory and Elias's (1976) theory of civilization highlight the existence of a 'core area' or a 'hegemon' as a prerequisite for such processes.

\subsection{International Society and Transnational Relations}

Compliance with regime rules entails the possibility of domestic redistribution of resources. A free-trade regime which favors producers and consumers or certain industrial sectors may hurt workers or other sectors. Such effects reach beyond the given issue area by empowering certain domestic groups and creating new coalitions that may influence the overall foreign policy of a state. Milner (1988) and Rogowski (1989), for example, demonstrate that international institutions empowered agents of liberalism in OECD countries, thus creating domestic structures that fostered the growth of a general foreign policy orientation that comes close to the ideal type of a trading state (Rosecrance, 1987). On this account, 'domestic social actors, not states, are the agents of interdependence’ (Milner, 1988: 291).

Similarly, international institutions can create opportunities and incentives for increased transnational activities on the part of various social actors and, as a result, for the emergence of influential transnational coalitions. These coalitions often stimulate social learning and promote orientations that favor international cooperation. Since the Single European Act strengthened the role of majority voting in the European Union and consequently weakened 
the effect of national vetoes, for example, many European interest groups have opened offices in Brussels (Streeck and Schmitter, 1991). In the process, this development has created new opportunities for the establishment of transnational networks. As students of international environmental politics have demonstrated, moreover, the formation of regimes can empower issue networks and stimulate the creation of epistemic communities (Haas, 1992). Although the immediate effects of the creation of such networks and communities are normally issue area specific, intensified transnational relations provide an important opportunity for ongoing social learning likely to have broader effects (Risse-Kappen, 1994; Leatherman et al., 1993). Older studies of transnational relations often emphasized this learning effect. Learning of this sort may involve both changes in the way cause-effect relationships are understood within and across issue areas and a better grasp of the intentions underlying the actions of others. It may also affect the way international actors think of their interests (Jachtenfuchs, 1993).

Moving onto constitutive matters, we turn first to the idea that the redistribution of domestic resources and the creation of transnational coalitions, taken together, may produce domestic repercussions leading to changes in internal political structures. Although this line of thinking is highly speculative, there is no reason to exclude it from a study of broader consequences of regimes, as work on the 'second image reversed' (e.g. Katzenstein, 1984) clearly demonstrates. Insofar as international regimes contribute to the rise of transnational issue networks, epistemic communities and transnational social movements, moreover, they contribute to the growth of challenges to traditional notions of sovereignty and community. In a sweeping statement, Camilleri and Falk (1992: 232) portray transnational movements as sources of 'support for a new system of multiple allegiances and jurisdictions, held together not by supreme authority but by an emerging world culture and a dynamic network of communities, movements and organizations'. As the European Union example demonstrates, shifts in policy-making hierarchies may also affect the loyalties of the populace and the boundaries of imagined communities in complex ways. Whereas European integration was accompanied for a long time by a growing sense of European identity on the part of many, a more nationalist counter-movement has recently emerged.

Tracing complex, long-term processes, such as the impact of international regimes on domestic structures and on the constitutive principles of international society poses a tremendous analytical challenge. Yet it seems important to tackle such matters in order to contribute to the discussion of 'big questions', involving issues like 'the diminished role of state sovereignty' and 'international governance'. Conclusive answers to these 
Marc A. Levy et al.

questions will not come from the study of individual regimes. Studies that cut across issue areas and that compare and contrast different regimes are needed in this context. The informational requirements for such studies are so great that they cannot be handled effectively by individual scholars working alone. The emergence of a number of large, collaborative projects dealing with international regimes is therefore an encouraging sign.

\section{The Road Abead}

What can we conclude from this survey about current gaps, growth areas and research priorities in the field of regime analysis? As documented in the preceding sections, regime analysis has established itself as a going concern - even a growth industry - among students of international relations. Despite some continuing debates about definitional matters, the concept of international regimes has emerged as an analytically robust construct encompassing a sizable universe of cases. Interest has shifted from an initial preoccupation with regime formation to a concentrated effort to understand when and how international institutions affect collective outcomes in international society, a positive sign in the sense that this is a matter that must be confronted successfully if regime analysis is to acquire intellectual staying power. What is more, major contributions to this line of inquiry are increasingly coming from Europe and beyond, so that it is fair to conclude that regime analysis is more than just another passing fancy of the American scholarly community (Rittberger, 1993b).

These are important achievements. But they should not distract us from a consideration of current gaps and future directions. In this final section, we turn to a consideration of the next phase of regime analysis, singling out a number of areas that require more concentrated attention and that show promise of being ripe for such attention in the sense that investments of time and energy in analyzing them now are likely to yield sizable dividends over the next five to ten years. The result is a science agenda for the field of regime analysis. This will pave the way for a brief concluding discussion of the role of a regimes database, the construction of which provided the initial stimulus for this state-of-the-art survey. To lend focus to the assessment that follows, we start each observation about growth areas and research priorities with a specific question.

1. How can we supplement contractarian thinking with other modes of thought (e.g. agent-structure analysis) in our efforts to understand the nature of international regimes? Most studies of regimes assume that potential regime members exist as fully functioning entities prior to the emergence of collective-action problems. On this account, actors whose identities, interests and preferences are determined through some exogenous process 
interact with each other in ways that generate collective-action problems and, at some point, realize that they may be able to eliminate or alleviate these problems by devising mutually agreeable institutional arrangements that will serve to guide their subsequent interactions. The obvious focus then is on the processes through which groups of actors endeavor, successfully or unsuccessfully, to arrive at social contracts establishing the constitutive rules of regimes. This line of analysis has proved rewarding; it has produced much of what we currently know about the dynamics of international regimes. Yet it is also important to reverse the relationship between actors and institutions and ask when and how prevailing institutions operate to determine, or at least influence, the identities and therefore the interests and preferences of the members of a social group. This is exactly what analysts like Alexander Wendt, using the agent-structure construct and arguing that social structure exerts a substantial influence on the identities of individual members of societies, have proposed (Wendt, 1987, 1992). There is a sense also in which the views of neorealists like Kenneth Waltz reflect this mode of thought (Waltz, 1979), and such perspectives will surely resonate with policy-makers acting on behalf of the 'new' states that have joined international society over the last 50 years. The implications of this reversal of the mainstream view of regimes are far reaching. For example, actors whose identities are derived, in part at least, from the character of the social institutions to which they belong will have a dramatically different view of the issue of compliance with institutional rules than those whose interests and preferences are independent of their institutional memberships. The point of drawing this distinction is not to argue that one or the other approach is correct. Rather, the challenge before us is to capitalize on the insights emerging from agent/structure perspectives without jeopardizing the achievements of mainstream contractarian analyses.

2. To what extent does problem structure or the pre-existing constellation of actor interests determine the outcomes of efforts to form regimes and the consequences flowing from regimes once they are in place? Basing their arguments on models of interactive decision-making, many regime analysts have focused on problem structures and interest constellations as determinants of success in efforts to solve collective-action problems. The game-theoretically inclined, for example, have drawn a distinction between coordination problems (for example, battle of the sexes) in which there are stable equilibria and collaboration problems (for instance, prisoner's dilemma or chicken) in which equilibria are either suboptimal or absent (Stein, 1983; Martin, 1992; Zürn, 1992). Whereas incentives to cheat and, therefore, concerns about the development of compliance mechanisms constitute a central concern in dealing with collaboration problems, there is much less need to worry about such matters in coming to terms with 
coordination problems. Others have focused on measures of the severity or intensity of conflicts of interest among interactive decision-makers - the idea of a spectrum ranging from pure cooperation to pure or zero-sum conflict is popular in such analyses - and argued that the intensity of conflicts of interest or the 'malignness' of problems is an important determinant not only of success in efforts to create institutions but also of the effectiveness of institutions once they are in place (Wettestad and Andresen, 1991). It is important to distinguish, on this account, between types of conflicts such as conflicts about values, which are the most difficult to solve, and conflicts about absolutely assessed goods, which are relatively easy to solve (Rittberger and Zürn, 1990). Such arguments all assume that problem structures and interest constellations are independent of the interactive process itself. Yet there are reasons to believe that many situations violate this assumption to a considerable extent. Participants in interactive decision-making seldom see themselves as operating in an environment in which the problem is fixed at the outset; their interactions frequently have an integrative or productive dimension in the sense that the parties learn more about the problem, invent new ways of thinking about it or even redefine the character of the problem itself in their dealings with each other. There is a sense, then, in which problems are malleable and problem structure is a variable affected by the interactions of participating actors. Under such conditions, actors may devise regimes that are mutually beneficial without ever spelling out definitively the structure of the problem they are seeking to solve. This is not to deny the insights arising from efforts to differentiate analytically distinct problem structures and constellations of interests. But it does suggest that we need to be cautious in drawing inferences about regime formation and problem-solving from such distinctions.

3. How should we deal with the fact that the members of international regimes - sovereign states for the most part - are complex collective entities rather than unitary actors? Understandably, most studies of regimes have treated the actors involved in the formation and operation of international institutions as rational utility maximizers weighing benefits and costs and making choices among clear options. The tractability of models based on this vision has played a vital role in producing valuable insights regarding the creation and operation of institutional arrangements. Yet this perspective abstracts away many important elements of the behavior of actors participating in international regimes. Most actors have crowded political agendas, so that efforts to deal with specific regimes are affected by the treatment of other issues unfolding simultaneously and may even be shunted aside in the rush to deal with more pressing concerns. When actors do focus on specific regimes, they are likely to experience internal disagreements over the relative merits of different institutional options at the international level. This is the 
essential idea behind the concept of two-level games, a perspective highlighting the fact that the positions actors adopt in international negotiations are products of domestic bargaining and that the course of international negotiations, in turn, can become a determinant of the course of domestic bargaining (Putnam, 1988). Nor do these complications come to an end once parties reach agreement on the terms of international regimes. On the contrary, the configuration of political forces affecting the implementation of international regimes may differ substantially from the line-up involved in regime formation. Under the circumstances, regimes in practice may differ significantly from the expectations of their creators; regimes agreed to on paper may even become non-starters or dead letters in practice. The point of these observations is not to deny the value of models assuming unitary actors but rather to highlight the need to supplement these models with analyses that recognize the internal processes determining the behavior of individual actors regarding the creation and operation of regimes.

4. What are the determinants of the willingness and ability of states to implement the provisions of international regimes in dealing with a variety of actors operating under their jurisdiction? A distinctive feature of international regimes is that there is often a separation between the members of these institutional arrangements (that is, states) and many of those whose behavior is their ultimate target (for example, banks, manufacturers, power plants, airlines, shipping companies, fishers). For this reason, the implementation of regimes normally requires states to translate the provisions of international agreements into domestic prescriptions (often, but not always, through the passage of implementing legislation) and to devise means of eliciting compliance from targets of these prescriptions who are subject to their jurisdiction. This arrangement has some attractions for those concerned about the effectiveness of international regimes (for example, it alleviates some concerns about the weakness of compliance mechanisms at the international level). At the same time, it highlights the importance of examining the willingness and the capacity of member states to implement the provisions of international regimes (Jacobson and Weiss, 1995; Hanf and Underdal, forthcoming). Predictably, states vary greatly in these terms. This is partly a matter of differences relating to political structures. States differ, for instance, in the extent to which the provisions of international agreements take precedence legally over municipal laws and in the extent to which opponents of international regimes are able to make their preferences felt in the policy process. More broadly, this topic directs attention to the importance of state-society relations in any examination of the effectiveness of international regimes. Thus, strong states may be better situated than 
weak states to guide the behavior of actors operating under their jurisdiction. Hierarchical states in which great authority is vested in the central government will find it easier to translate the provisions of international regimes into national law than decentralized systems in which the central government has limited authority over regional and local governments. Similarly, states that own or directly control large segments of the means of production in their societies should find it easier to exercise control over actor behavior than those operating in social settings featuring private property and strict limits on the regulatory authority of the state. Yet it remains an open question what kind of domestic structure most effectively changes behavioral patterns toward regime goals. It follows that simple generalizations about the domestic implementation of regime provisions need to be scrutinized with care.

5. To what extent do we need to supplement (or supplant) the enforcement) sanctions model in thinking about compliance with the terms of international regimes? Much thinking about social institutions rests on the (often implicit) assumption that the probability of being caught and punished is a key determinant of whether subjects elect to comply with or to violate the rules. On this account, the absence of a central government capable of enforcing the provisions of international regimes is a critical weakness of international society. In the eyes of some, this problem casts doubt on the whole enterprise of regime analysis. But this argument rests on a limited understanding of the bases of compliance at every level of social organization. The imposition of sanctions by central governments is not a critical basis of compliance with many domestic laws and other prescriptions (Young, 1979). Levels of compliance are respectably high with regard to the rules of many, though by no means all, international regimes. This suggests that we need to think systematically about other bases of compliance and the conditions that determine their relevance to various issue areas (Chayes and Chayes, 1993, 1995; Mitchell, 1993). How important is transparency and various procedures for monitoring and implementation review that often go with it? What is the role of social pressure, in contrast to sanctions imposed by public authorities, as a determinant of compliance with international rules? Do feelings of ownership arising from meaningful participation in rule-making processes and the sense of legitimacy that such feelings engender make a difference when it comes to compliance with the rules? The point of raising these questions is not to replace the conventional enforcement/sanctions model of compliance with some simple alternative. They indicate, instead, that numerous bases of compliance may operate simultaneously or play different roles in various issue areas, so that there is a need for much greater sophistication in efforts to explain or predict levels of compliance with the provisions of specific regimes. 
6. What is the role of non-state actors in the creation and operation of international regimes? Despite the arguments presented by those who speak of the emergence of a global civil society (Lipschutz, 1992; Wapner, 1992), there is not yet much evidence for concluding that states are losing their place as the dominant (normally sole) members of international regimes. Yet this conclusion is not inconsistent with the observation that numerous nonstate actors are gaining influence not only in processes of regime creation but also in the administration of regimes at the international level and the implementation of regimes within municipal forums (Princen and Finger, 1994). Non-governmental organizations regularly play important roles in framing issues and designing the provisions of international regimes. Increasingly, they are represented on national delegations and are allowed to make presentations in their own right during negotiations giving rise to new institutions. These organizations have gained access as well to many of the commissions and scientific committees established to administer regimes at the international level. They loom large in many cases as watchdogs, publicizing non-compliant or ambiguous behavior on the part of regime members and bringing pressure to bear on international commissions to take their mandates seriously and to confront sensitive issues squarely. There is ample evidence to suggest, moreover, that both the desire and the capacity of these organizations to intervene in such matters is growing across a wide range of issue areas. What this suggests is that we need to set aside sterile arguments about the decline of the nation-state and the rise of non-state actors and get on with the analysis of the roles non-state actors actually play in a society whose membership is still composed largely of states. This should increase the subtlety and sophistication of our grasp of international regimes, without requiring any fundamental alteration of the basic idea that regimes are social institutions created by states to eliminate or alleviate collectiveaction problems at the international level (Haufler, 1993).

7. How should we deal with institutional linkages among differentiable regimes operative in international society? For the most part, analyses of international regimes have focused on individual arrangements on the assumption that they are self-contained or stand-alone institutions to be studied in isolation from one another. This procedure has obvious attractions from the point of view of tractability; it has undoubtedly aided in our initial efforts to understand the nature and significance of regimes. Yet it is apparent that institutional linkages are widespread - and becoming more so - in international society. Specific regimes are often embedded in larger systems of norms and principles, such as the liberal international economic order of the postwar period (Ruggie, 1983). Individual provisions are regularly nested into overarching frameworks, as in the case of substantive protocols set into the context of a broader framework agreement. Two or 
more regimes created for entirely different purposes can intersect with each other with far-reaching consequences, as we have come to realize in recent years in the context of the environment and trade debate. Just as we have learned to think systematically about issue linkages in the creation and operation of individual regimes, therefore, we must now turn our attention to institutional linkages. This should help us to understand questions concerning such matters as the conditions under which existing regimes spawn additional institutions, regimes created for separate purposes interfere with each other's operation, and initially unrelated regimes grow together to form larger institutional complexes governing relations among groups of actors in international society.

8. Do international regimes exhibit identifiable life cycles, and can we develop propositions about processes of regime growth and decay? Although regime formation has occupied center stage in the field of regime analysis, many observers have noted that regimes change continuously over time and that some regimes decline or go out of existence even as others are coming on stream. Interestingly, trajectories of regime decay appear to vary greatly. Some regimes acquire a life of their own and remain intact long after the forces that produced them have dissipated or shifted to other issues. In other cases, regimes that have proved effective for relatively long periods collapse quickly as circumstances (often, but not always, involving technological developments) change. It is clear, even at this early stage, that regime decay or, more broadly, regime change is not some simple function of shifts in the configuration of power in the material sense; there is therefore little likelihood that we can explain or predict the course of regime change by constructing some index of shifts in the distribution of structural power. This may seem disappointing from the point of view of analytic tractability. But it opens up a large and important area of inquiry relating to international regimes that has not been pursued systematically by students of institutions. Treating institutional change as the dependent variable, studies of this kind present attractive opportunities for examining the relative importance of material conditions (for example, shifts in population densities or patterns of economic growth) and ideas (for instance, the growing concern for anthropogenic change in large natural systems) as determinants of regime change. Such studies may also shed light on the extent to which regimes themselves are self-maintaining in the sense that they have built-in mechanisms allowing them to adjust or adapt to changes in the natural and social environments within which they operate.

9. How can we combine the insights of the rationalists and the reflectivists (Keobane, 1989) to improve our understanding of international regimes? It is probably fair to say that the largest single strand of regime analysis is the work of those who adhere to one variety or another of neopositivism (often 
called rationalists) in search of generalizations that can be linked to empirical observations in a more or less straightforward manner. We belong to this group ourselves. Yet it is important to point out that the analysis of international regimes has attracted the attention of a number of scholars (sometimes called reflectivists) who bring other approaches to knowledge and evidence to this endeavor (Kohler-Koch, 1989). This second stream of work includes a variety of components, such as the historicism of those who have looked at regimes as path-dependent constructs, the linguistic and legal analyses of those who have endeavored to sort out different types of rules, and the critical theory of those who see regimes as expressions of larger social forces at work in human affairs (Keeley, 1990; Hurrell, 1993; Kratochwil, 1993). Taken together, the contributions of these reflexivist scholars have added a number of dimensions to our understanding of the nature and role of institutions in international society. The challenge confronting us now is to devise methods for drawing on both of these streams of analysis in the interests of developing a deeper understanding of international regimes than either body of work alone can support. This will not be an easy task. Not only is it difficult to frame the findings of the rationalists in reflexivist terms and vice versa, but there is also a tendency on the part of both groups to disparage the contributions of the other. Yet the future of regime analysis may well turn in considerable measure on our ability to find the language and analytic procedures needed to bridge this gap.

10. Can we derive design principles from the study of international regimes that will prove useful to practitioners responsible for creating or restructuring such institutional arrangements? The appeal of translating the findings of regime analysis into design principles is easy to understand. It provides scholars with the satisfaction of feeling that their work is relevant to the world of social policy. Equally important, it makes the world of research useful to policy-makers and offers a justification for continuing to support the endeavors of scholars. Yet the gap between regime analysis in its current form and the design of specific international institutions is wide. Partly, this is a matter of the presence of sharp differences of opinion among students of regimes and the resultant lack of consensus within this community on the formulation of powerful generalizations. In part, it is a consequence of the contingent nature of most propositions about the creation and operation of international regimes. What this means is that conclusions drawn from one set of cases or from one issue area frequently fail to generalize to others, and analysts are seldom in a position to make clear predictions regarding the consequences likely to flow from the choice of specific institutional arrangements to deal with current problems. To this we must add that the creation of regimes in international society normally involves the give-andtake of institutional bargaining, so that the institutions that emerge are 
hybrid arrangements arising from deals made in the interests of reaching closure in the bargaining process. Although hybrid vigor may be a common phenomenon in other realms, there is no basis for expecting such mixed arrangements to produce particularly desirable outcomes in the realm of international institutions. Nonetheless, we cannot and should not abandon the search for usable design principles in the analysis of international regimes. The case for combining theory and praxis in this field of analysis is compelling both from the perspective of those seeking to add to our knowledge of international institutions and from the vantage point of those responsible for creating and operating them.

To conclude, we offer some brief observations regarding the relationship between this survey of regime analysis and the creation of the regimes database that led us to undertake this assessment in the first place. The dominant methodology among students of international regimes features the conduct of structured and focused case studies. Such studies have the virtue of providing empirically grounded and detailed accounts of actual regimes. But they leave much to be desired in terms of the generalizability of their findings. For the most part, the cases chosen for analysis do not constitute representative samples of the larger universe of international regimes. In many instances, there are legitimate concerns regarding the influence of selection bias in the choice of cases. This makes it difficult to conduct natural experiments featuring comparisons of situations with and without regimes; it virtually precludes studies focusing on variance in the classificatory variables we outlined in Section 2 of this article.

What is needed to alleviate this problem is a database containing comparable information on a growing collection of regimes. The development of such a database must begin with clear and uniform criteria for identifying regimes, so that we can be sure we are dealing with a welldefined universe of cases that are homogeneous with regard to their defining characteristics. We must then proceed to add a set of variables that are conceptually consistent in the sense that key concepts are used in the same way by all those contributing to the database and that are calibrated in the sense that procedures for taking readings on these variables are uniform. Building such a database can play a critical role in pursuing the science agenda set forth in the preceding pages; the research program outlined here will also contribute to the continuing growth of the database. To be sure, this effort is most relevant to the research agenda of those who operate within the realm of neopositivism broadly construed. This is a significant limitation; we must not allow the development of a regimes database to deflect our attention from the need to find ways to integrate the contributions of the rationalists and the reflexivists. In the realm of 
empirically grounded efforts to construct generalizations or to probe causal mechanisms, however, the regimes database should become a powerful and widely used tool in efforts to expand our understanding of the role of institutions in coping with difficult international problems.

\section{Notes}

The writing of this article was supported by the International Environmental Commitments project of the International Institute for Applied Systems Analysis (IIASA), Laxenburg, Austria. We are grateful to the IIASA for its support; and to Hua Dong and Cara Morris for assistance in preparing the manuscript. Peter Mayer and Ron Mitchell provided helpful comments on an earlier draft.

1. In their article eloquently entitled 'International Organization: A State of the Art on the Art of the State', Friedrich Kratochwil and John Ruggie 1986, provide an intellectual history of the development of research on international organizations rather than a report on the study of international regimes.

2. 'International regimes are defined as principles, norms, rules, and decisionmaking procedures around which actor expectations converge in a given issue-area' (Krasner 1983b: 2).

3. This definition meshes well with influential formulations by Keohane (1989: 3), who sees institutions as 'persistent and connected sets of rules (formal and informal) that prescribe behavioral roles, constrain activity, and shape expectations' and by Young (1989: 5), who defines institutions as 'identifiable practices of recognized roles linked by clusters of rules or conventions governing relations among the occupants of these roles'.

4. 'Patterned behavior' as an operational measure of regimes was suggested by Puchala and Hopkins (1983: 63).

5. The assessment of rule-consistent behavior does not require causal statements, as the assessment of rule-guided behavior would.

6. This operational version of the consensus definition emerged as a result of lengthy discussions during a 'Regimes Summit' held at Dartmouth College during November 1991. See Oran Young (1991b). This report includes a list of participants in the discussions. See also Keohane (1993: 26-9), Rittberger (1993b: 8-11), Zürn (1992: 140-6).

7. See Kreile (1989) referring to Harald Müller's (1989) excellent account of the 'non-proliferation Regime' that would have been weaker analytically if the distinction between principles, norms, rules and decision-making procedures had not been applied.

8. In practice, international organizations and international regimes are often closely intermeshed. Specific international organizations regularly perform a number of functions for international regimes, including monitoring, information-gathering and rule-revising. On the other hand, international organizations can operate as regime-making mechanisms (e.g. the CSCE in the development of many East-West regimes). 
9. Keohane's (1989:4) use of the term 'convention' differs from ours. He refers to implicit rules and understandings (without telling us how to identify them). His notion of conventions is clearly different from that of Lewis, who would describe dress codes as conventions, whether or not they are explicitly stated.

10. At another point, Ostrom (1990: 52) also distinguishes between operational, collective-choice and constitutional rules. This distinction resembles the one between substantive and decision-making rules suggested in the regime definition.

11. A separate distinction deals with the degree to which regime members are conscious of the contents of a regime's rules and able to articulate them clearly. Informal rules may be explicit in the sense that analysts have no trouble identifying them clearly, even though regime members may have difficulty articulating them.

12. Besides being robust with respect to a given constellation of interests, however, international regimes may foster learning processes that make the constellation of international interests more conducive to institutionalized cooperation. The GATT regime may be construed as an example of this phenomenon. See Milner (1988), Rogowski (1989) and Section 6 of this article.

13. Yet even the process of transition shows signs of regime robustness. The degree to which new states, such as Russia and Ukraine, are willing to take on the institutional commitments of the former Soviet Union can hardly be accounted for without referring to factors like regime robustness. See Schimmelfennig (1994).

14. Some environmentalists have criticized efforts to improve safety provisions for East European and former Soviet nuclear reactors on these grounds.

15. The Dartmouth project on effectiveness distinguishes 'first order effectiveness' (a correlation of raw outcomes) from 'sophisticated effectiveness' (a correlation combined with a demonstration of causal links).

16. This section draws liberally from Levy (1993b).

17. Because most of the studies referred to in this paragraph were not aimed at answering questions about effectiveness, this shortcoming does not necessarily reflect negatively on them.

\section{References}

Andresen, Steinar (1989) 'The Environmental North Sea Regime: A Successful Regional Approach', in Elisabeth Mann-Borgese et al. (eds) Ocean Yearbook 8, pp. 378-401. Chicago, IL: University of Chicago Press.

Axelrod, Robert (1984) The Evolution of Cooperation. New York: Basic Books.

Beck, Peter (1986) The International Politics of Antarctica. London: Croom Helm.

Biersteker, Thomas (1993) 'Constructing Historical Counterfactuals to Assess the Consequences of International Regimes: The Global Debt Regime and the Course of the Debt Crisis of the 1980s', in Volker Rittberger (ed.) Regime Theory and International Relations, pp. 315-38. Oxford: Clarendon Press. 
Boehmer-Christiansen, Sonja (1989) 'The Role of Science in the International Regulation of Pollution', in Steinar Andresen and Wily Ostreng (eds) International Resource Management, pp. 143-67. London: Belhaven Press.

Breitmeier, Helmut, Thomas Gehring, Martin List and Michael Zürn (1993) 'Internationale Umweltregime', in Volker von Prittwitz (ed.) Umweltpolitik als Modernisierungsprozeß, pp. 163-92. Opladen: Leske und Budrich.

Burley, Anne-Marie (1993) 'Regulating the World: Multilateralism, International Law, and the Protection of the New Deal Regulatory State', in John Gerard Ruggie (ed.) Multilateralism Matters: The Theory and Praxis of an Institutional Form, pp. 125-56. New York: Columbia University Press.

Campbell, Donald and Julian Stanley (1966) Experimental and Quasi-Experimental Designs for Research. Chicago, IL: Rand McNally.

Camilleri, Joseph A. and Jim Falk (1992) The End of Sovereignty. The Politics of a Shrinking and Fragmenting World. Aldershot: Edgar Elgar.

Caporaso, James (1992) 'International Relations Theory and Multilateralism: The Search for Foundations', International Organizations 46: 599-632.

Chayes, Abram and Antonia Chayes (1993) 'On Compliance', International Organization 47: 175-205.

Chayes, Abram and Antonia Chayes (1995) The New Sovereignty. Cambridge, MA: Harvard University Press.

Coleman, James S. (1990) Foundations of Social Theory. Cambridge, MA: Harvard University Press.

Cox, Robert W. (1983) 'Gramsci, Hegemony, and International Relations: An Essay in Method', Millennium 12(2): 162-75.

Cox, Robert W. and Harold K. Jacobson (1973) The Anatomy of Influence. DecisionMaking in International Organizations. New Haven, CT: Yale University Press.

de Senarclens, Pierre (1993) 'Regime Theory and the Study of International Organizations', International Social Science Journal 45(4): 453-62.

Deutsch, Karl W. et al. (1957) Political Community and the North Atlantic Area. International Organizations in the Light of Historical Experience. Princeton, NJ: Princeton University Press.

Downs, George W. and David M. Rocke (1990) Tacit Bargaining, Arms Races and Arms Control. Ann Arbor: University of Michigan Press.

Efinger, Manfred, Volker Rittberger, Klaus Dieter Wolf and Michael Zürn (1990) 'Internationale Regime und internationale Politik', in Volker Rittberger (ed.) Theorien der internationalen Beziehungen, PVS-Sonderheft 21: 263-85.

Efinger, Manfred, Peter Mayer and Gudrun Schwarzer (1993) 'Integrating and Contextualizing Hypotheses: Alternative Paths to Better Explanations of Regime Formation?', in Volker Rittberger (ed.) Regime Theory and International Relations, pp. 252-81. Oxford: Clarendon Press.

Elias, Norbert (1976) Über den Prozeß der Zivilisation: Soziogenetische und Psychogenetische Untersuchungen, Vol. 1. Frankfurt am Main: Suhrkamp.

Ellickson, Robert (1991) Order Without Law: How Neighbors Settle Disputes. Cambridge, MA: Harvard University Press. 
Evans, Peter B., Harold K. Jacobson and Robert D. Putnam (eds) (1993) Doubleedged Diplomacy: International Bargaining and Domestic Politics. Berkeley: University of California Press.

Fearon, J. (1991) 'Counterfactuals and Hypothesis Testing in Political Science', World Politics 43(2): 169-85.

Franck, Thomas M. (1990) The Power of Legitimacy among Nations. Oxford: Oxford University Press.

Freeman, John R. and Cynthia A. Cannizo (1981) 'Constitutions, Covenants, and Charters: An Analysis of Decision Rules in International Organizations', Journal of Peace Research 18(3): 277-90.

Geertz, Clifford (1973) The Interpretation of Cultures: Selected Essays. New York: Basic Books.

Gehring, Thomas (1994) Dynamic International Regimes: Institutions for International Environmental Governance. Frankfurt am Main: Peter Lang.

Gilpin, Robert (1987) The Political Economy of International Relations. Princeton, NJ: Princeton University Press.

Grieco, Joseph M. (1990) Cooperation among Nations: Europe, America, and NonTariff Barriers to Trade. Ithaca, NY: Cornell University Press.

Haas, Ernst B. (1990) When Knowledge is Power: Three Models of Change in International Organizations. Berkeley: University of California Press.

Haas, Peter M. (1989) 'Do Regimes Matter? Epistemic Communities and Mediterranean Pollution Control', International Organization 43(3): 377-403.

Haas, Peter M. (1990) Saving the Mediterranean: The Politics of International Environmental Cooperation. New York: Columbia University Press.

Haas, Peter M. (ed.) (1992) 'Knowledge, Power, and International Policy Coordination', Special Issue of International Organization 46(1).

Haas, Peter M., Robert O. Keohane and Marc A. Levy (eds) (1993) Institutions for the Earth: Sources of Effective International Environmental Protection. Cambridge, MA: MIT Press.

Haggard, Stephan and Beth A. Simmons (1987) 'Theories of International Regimes', International Organization 41(3): 491-517.

Hanf, Kenneth and Arild Underdal (forthcoming) 'Domesticating International Commitments: Linking National and International Decision-making', in Arild Underdal (ed.) The International Politics of Environmental Management. Dordrecht: Kluwer.

Hart, H.L.A. (1961) The Concept of Law. Oxford: Clarendon Press.

Haufler, Virginia (1993) 'Crossing the Boundary between Private and Public: International Regimes and Non-State Actors', in Volker Rittberger (ed.) Regime Theory and International Relations, pp. 94-111. Oxford: Clarendon Press.

Hurrell, Andrew (1993) 'International Society and the Study of Regimes: A Reflective Approach', in Volker Rittberger (ed.) Regime Theory and International Relations, pp. 49-72. Oxford: Clarendon Press.

Jachtenfuchs, M. (1993) 'Ideen und Interessen: Weltbilder als Kategorien der politischen Analyse', mimeo, Mannheimer Zentrum für Europäische Sozialforschung. 
Jacobson, Harold K. and Edith Brown Weiss (1990) 'Implementing and Complying with International Environmental Accords: A Framework for Research', paper prepared for the annual meeting of the American Political Science Association, San Francisco.

Jacobson, Harold K. and Edith Brown Weiss (1995) 'Strengthening Compliance with International Environmental Accords: Preliminary Observations from a Collaborative Project, Global Governance 1(2): 119-48.

Kay, David A. and Harold K. Jacobson (eds) (1983) Environmental Protection: The International Dimension. Totowa, NJ: Allanheld, Osmun.

Katzenstein, P.J. (1984) Corporatism and Change. Ithaca, NY: Cornell University Press.

Keck, Otto (1991) 'Der neue Institutionalismus in der Theorie der internationalen Politik', Politische Vierteljahresschrift 32(4): 635-53.

Keeley, J.F. (1990) 'Toward a Foucauldian Analysis of International Regimes', Intenational Organization 44(1): 83-105.

Keohane Robert O. (1984) After Hegemony. Cooperation and Discord in the World Political Economy. Princeton, N.J.: Princeton University Press.

Keohane, Robert O. (1989) International Institutions and State Power. Essays in International Relations Theory. Boulder, CO: Westview Press.

Keohane, Robert O. (1993) 'The Analysis of International Regimes: Towards a European-American Research Programme', in Volker Rittberger (ed.) Regime Theory and International Relations, pp. 23-48. Oxford: Clarendon Press.

Kohler-Koch, Beate (ed.) (1989) Regime in den Internationalen Beziehungen; Baden-Baden: Nomos.

Krasner, Stephen D. (1976) 'State Power and the Structure of International Trade', World Politics 28(3): 317-47.

Krasner, Stephen D. (ed.) (1983a) International Regimes. Ithaca, NY and London: Cornell University Press.

Krasner, Stephen D. (1983b) 'Structural Causes and Regime Consequences: Regimes as Intervening Variables', in Krasner (ed.) International Regimes, pp. 1-22. Ithaca, NY and London: Cornell University Press.

Krasner, Stephen D. (1985) Structural Conflict. The Third World Against Global Liberalism. Berkeley: University of California Press.

Krasner, Stephen D. (1991) 'Global Communications and National Power: Life on the Pareto Frontier', World Politics 43(3): 336-66.

Kratochwil, Friedrich (1993) 'Contract and Regimes: Do Issue Specificity and Variations of Formality Matter?', in Volker Rittberger (ed.) Regime Theory and International Relations, pp. 73-93. Oxford: Clarendon Press.

Kratochwil, F. and J.G. Ruggie (1986) 'International Organization: A State of the Art or an Art of the State', International Organization 40(4): 753-75.

Kreile, M. (1989) 'Regime und Regimewandel in den internationalen Wirtschaftsbeziehungen', in Beate Kohler-Koch (ed.) Regime in den Internationalen Beziebungen, pp. 89-104. Baden-Baden: Nomos.

Leatherman, Janie, Ron Pagnucco and Jackie Smith (1993) 'International Institutions and Transnational Social Movement Organization: Challenging the State in 
a Three-Level-Game of Global Transformation', mimeo, Kroc Institute for International Peace Studies, University of Notre Dame.

Lee, Kai N. (1993) Compass and Gyroscope: Integrating Science and Politics for the Environment. Washington, DC: Island Press.

Levy, Marc A. (1993a) 'European Acid Rain: The Power of Tote-Board Diplomacy', in Peter M. Haas, Robert O. Keohane and Marc A. Levy (eds) Institutions for the Earth: Sources of Effective International Environmental Protection, pp. 75-132. Cambridge, MA: MIT Press.

Levy, Marc A. (1993b) 'Political Science and the Question of Effectiveness of International Environmental Institutions', International Challenges 13(2): $17-35$.

Levy, Marc A. and Oran R. Young (1993) 'Results of the November Workshop', memorandum to members of research project on Effectiveness of International Environmental Regimes (14 January).

Levy, Marc A. and Oran R. Young (1994) 'The Effectiveness of International Regimes', paper presented at annual convention of the International Studies Association, Washington DC (29 March-1 April).

Lewis, David K. (1969) Conventions. Cambridge, MA: Harvard University Press.

Lipschutz, Ronnie (1992) 'Restructuring World Politics: The Emergence of Global Civil Society', Millenium 21(3): 389-420.

Lipson, Charles (1991) 'Why Are Some International Agreements Informal?' International Organization 45(4): 495-538.

List, Martin (1991) Umweltschutz in zwei Meeren. Munich: Tuduv.

Lister, Frederick K. (1984) 'Decision-making Strategies for International Organizations: The IMF Model', Monograph Series in World Affairs, University of Denver.

Lowi, Theodore J. (1964) 'American Business, Public Policy, Case Studies and Political Theory', World Politics 15(3): 677-715.

Lynn-Jones, Sean (1988) 'The Incidents at Sea Agreement', in Alexander L. George, Philip J. Dallin and Alexander Dallin (eds) US-Soviet Security Cooperation. Achievement, Failures, Lessons, pp. 482-509. Oxford: Oxford University Press.

McGinnis, Michael and Elinor Ostrom (1992) 'Design Principles for Local and Global Commons', paper prepared for presentation at a conference on Linking Local and Global Commons, Harvard University (23-5 April).

Martin, Lisa L. (1992) 'Interests, Power and Multilateralism', International Organization 46(4): 765-92.

Mayer, Peter, Volker Rittberger and Michael Zürn (1993) 'Regime Theory: State of the Art and Perspectives', in Volker Rittberger (ed.) Regime Theory and International Relations, pp. 391-430. Oxford: Clarendon Press.

M'Gonigle, R. Michael and Mark W. Zacher (1979) Pollution, Politics, and International Law: Tankers at Sea. Berkeley: University of California Press.

Miles, Ed (1989) 'Scientific and Technological Knowledge and International Cooperation in Resource Management', in Steinar Andresen and Wily Ostreng (eds) International Resource Management, pp. 46-87. London: Belhaven Press. 
Milner, Helen (1988) Resisting Protectionism. Global Industries and the Politics of International Trade. Princeton, NJ: Princeton University Press.

Milner, Helen (1993) 'International Regimes and World Politics: Comments on the Articles by Smouts, de Senarclens and Jönsson', International Social Science Journal 45(4): 491-7.

Mirovitskaya, Natalia S., Margaret Clark and Ronald G. Purver (1993) 'North Pacific Fur Seals: Regime Formation as a Means of Resolving Conflict', in Oran R. Young and Gail Osherenko (eds) Polar Politics: Creating International Environmental Regimes, pp. 22-55. Ithaca, NY: Cornell University Press.

Mitchell, Ronald B. (1993) 'Intentional Oil Pollution of the Oceans', in Peter M. Haas, Robert O. Keohane and Marc A. Levy (eds) Institutions for the Earth: Sources of Effective International Environmental Protection, pp. 183-248. Cambridge, MA: MIT Press.

Mitchell, Ronald B. (1994a) Intentional Oil Pollution at Sea: Environmental Policy and Treaty Compliance. Cambridge, MA: MIT Press.

Mitchell, Ronald B. (1994b) 'Regime Design Matters: Intentional Oil Pollution and Treaty Compliance', International Organization 48(3): 425-58.

Moe, Terry (1991) 'Politics and the Theory of Organization', Journal of Law, Economics, and Organization 7(1): 106-29.

Moravcsik, Andrew (1992) 'Liberalism and International Relations Theory', Working Paper No. 92-6, Center for International Affairs, Harvard University.

Müller, Harald (1989) 'Regimeanalyse und Sicherheitspolitik: Das Beispiel Nonproliferation', in Beate Kohler-Koch (ed.) Regime in den Internationalen Beziehungen, pp. 277-313. Baden-Baden: Nomos.

Müller, Harald (1993a) Die Chance der Kooperation: Regime in den Internationalen Beziehungen. Darmstadt: Wissenschaftliche Buchgesellschaft.

Müller, Harald (1993b) 'The Internalization of Principles, Norms and Rules by Governments: The Case of Security Regimes', in Volker Rittberger (ed.) Regime Theory and International Relations, pp. 361-90. Oxford: Clarendon Press.

Nye, Joseph S. (1987) 'Nuclear Learning and US Soviet Security Regimes', International Organization 41(3): 371-402.

Olson, Mancur Jr (1965) The Logic of Collective Action: Public Goods and the Theory of Groups. Cambridge, MA: Harvard University Press.

Ostrom, Elinor (1990) Governing the Commons. The Evolution of Institutions for Collective Action. Cambridge: Cambridge University Press.

Parson, Edward A. (1993) 'Protecting the Ozone Layer', in Peter M. Haas, Robert O. Keohane and Marc A. Levy (eds) Institutions for the Earth: Sources of Effective International Environmental Protection, pp. 27-74. Cambridge, MA: MIT Press.

Parson, Edward A. and Richard Zeckhauser (forthcoming) 'The Unbalanced Commons', in K. Arrow et al. (eds) Barriers to the Negotiated Resolution of Conflict. New York: Norton.

Peterson, M.J. (1992) 'Whales, Cetologists, Environmentalists and the International Management of Whaling', International Organization 46: 147-86. 
Princen, Thomas E. and Matthias Finger (eds) (1994) Environmental NGOs in World Politics: Linking the Local and the Global. London: Routledge.

Puchala, Donald J. and Raymond F. Hopkins (1983) 'International Regimes: Lessons from Inductive Analysis', in Stephen D. Krasner (ed.) International Regimes, pp. 61-91. Ithaca, NY and London: Cornell University Press.

Putnam, Robert D. (1988) 'Diplomacy and Domestic Politics: The Logic of TwoLevel Games', International Organization 42(3): 427-60.

Risse-Kappen, Thomas (1994) 'Ideas Do Not Float Freely - Transnational Coalitions, Domestic Structures, and the End of the Cold War', International Organization 48(2): 185-214.

Rittberger, Volker (ed.) (1990) International Regimes in East-West Politics. London: Pinter.

Rittberger, Volker (ed.) (1993a) Regime Theory and International Relations. Oxford: Clarendon Press.

Rittberger, Volker (1993b) 'Research on International Regimes in Germany: The Adaptive Internalization of an American Social Science', in Volker Rittberger (ed.) Regime Theory and International Relations, pp. 3-22. Oxford: Clarendon Press.

Rittberger, Volker and Michael Zürn (1990) 'Towards Regulated Anarchy in EastWest Relations: Causes and Consequences of East-West Regimes', in Volker Rittberger (ed.) International Regimes in East-West Politics, pp. 9-63. London: Pinter.

Rittberger, Volker, Manfred Efinger and Martin Mendler (1990) 'Toward an EastWest Security Regime: The Case of Confidence- and Security-building Measures', Journal of Peace Research 27(1): 55-74.

Rogowski, Ronald (1989) Commerce and Coalitions. How Trade Affects Domestic Realignments. Princeton, NJ: Princeton University Press.

Rosecrance, Richard (1987) The Trading State. New York: Basic Books.

Ruggie, John Gerard (1983) 'International Regimes, Transactions, and Change: Embedded Liberalism in the Postwar Economic Order', in Stephen D. Krasner (ed.) International Regimes, pp. 195-232. Ithaca, NY and London: Cornell University Press.

Ruggie, John Gerard (1992) 'Multilateralism: The Anatomy of an International Institution', International Organization 46(3): 561-98.

Sand, Peter (1990) Lessons Learned in Global Environmental Governance. Washington, DC: World Resources Institute.

Schelling, Thomas C. (1960) The Strategy of Conflict. Cambridge, MA: Harvard University Press.

Schelling, Thomas C. (1978) Micromotives and Macrobebavior. New York: Norton.

Schimmelfenning, Frank (1994) 'Arms Control Regimes and the Dissolution of the Soviet Union: Realism, Institutionalism, and Regime Robustness', Cooperation and Conflict 29(2): 115-34.

Schotter, Andrew (1981) The Economic Theory of Social Institutions. Cambridge: Cambridge University Press. 
Schwarzer, Gudrun (1990) 'The Berlin Regime', in Volker Rittberger (ed.) International Regimes in East-West Politics, pp. 189-215. London: Pinter.

Singh, Elen C. and Artemy A. Saguirian (1993) 'The Svalbard Archipelago: The Role of Surrogate Negotiators', in Oran R. Young and Gail Osherenko (eds.) Polar Politics Creating International Environmental Regimes, pp. 56-95. Ithaca, Cornell University Press.

Snidal, Duncan (1985a) 'Coordination versus Prisoner's Dilemma: Implications for International Cooperation and Regimes', American Political Science Review 79(4): 923-42.

Snidal, Duncan (1985b) 'Limits of Hegemonic Stability Theory', International Organization 39(4): 579-614

Soroos, Marvin S. (1993) 'Arctic Haze and Transboundary Air Pollution: Conditions Governing Success and Failure', in Oran R. Young and Gail Osherenko (eds) Polar Politics Creating International Environmental Regimes, pp. 186-222. Ithaca, NY: Cornell University Press.

Stein, Arthur A. (1983) 'Coordination and Collaboration: Regimes in an Anarchic World', in Stephen D. Krasner (ed.) International Regimes, pp. 115-40. Ithaca, NY and London: Cornell University Press.

Stein, Janice Gross (ed.) (1989) Getting to the Table: The Processes of International Prenegotiation. Baltimore, MD: Johns Hopkins University Press.

Strange, Susan (1983) 'Cave! Hic Dragones: A Critique of Regime Analysis', in Stephen D. Krasner (ed.) International Regimes, pp. 337-54. Ithaca, NY and London: Cornell University Press.

Streeck, W. and P.C. Schmitter (1991) 'From National Corporatism to Transnational Pluralism: Organized Interests in the Single European Market', Politics and Society 19(2): 133-64.

Susskind, Lawrence E. (1994) Environmental Diplomacy: Negotiating More Effective Global Agreements. New York: Oxford University Press.

Ullmann-Margalit, Edna (1977) The Emergence of Norms. Oxford: Oxford University Press.

Underdal, Arild (1992) 'The Concept of Regime "Effectiveness" ', Cooperation and Conflict 27(3): 227-40.

Vernon, Raymond (1993) 'Behind the Scenes: How Policymaking in the European Community, Japan, and the United States Affects Global Negotiations', Environment 35(5): $12-20$ and 35-43.

Waltz, Kenneth (1979) Theory of International Politics. Reading, MA. AddisonWesley.

Wapner, Paul (1992) 'Environmental Activism in World Civic Politics', paper prepared for the annual convention of the International Studies Association, Atlanta.

Wendt, Alexander E. (1987) 'The Agent-Structure Problem in InternationalRelations Theory', International Organization 41(3): 335-70.

Wendt, Alexander E. (1992) 'Anarchy Is What States Make of it - The Social Construction of Power-Politics', International Organization 46(2): 391-425. 
Marc A. Levy et al.

Wettestad, Jørgen and Steinar Andresen (1991) The Effectiveness of International Resource Cooperation: Some Preliminary Findings. Oslo: Fridtjof Nansen Institute.

Wolf, Klaus Dieter (1991) Internationale Regime zur Verteilung globaler Ressourcen. Baden-Baden: Nomos.

Wolf, Klaus Dieter and Michael Zürn (1986) “"International Regimes" und Theorien der internationalen Politik', Politische Vierteljabresschrift 27(2): 201-21.

Young, Oran R. (1979) Compliance and Public Authority: A Theory with International Appliance. Baltimore, MD: Johns Hopkins University Press.

Young, Oran R. (1983) 'Regime Dynamics: The Rise and Fall of International Regimes', in Stephen D. Krasner (ed.) International Regimes; pp. 93-113. Ithaca, NY: Cornell University Press.

Young, Oran R. (1989a) International Cooperation. Building Regimes for Natural Resources and the Environment. Ithaca, NY and London: Cornell University Press.

Young, Oran R. (1989b) 'The Politics of International Regime Formation: Managing Natural Resources and the Environment', International Organization 43(3): $349-75$.

Young, Oran R. (1991a) 'Political Leadership and Regime Formation: On the Development of Institutions in International Society', International Organization 45(3): 281-308.

Young, Oran R. (1991b) Report on the 'Regimes Summit', Minary Center, Dartmouth College (23-4 November).

Young, Oran R. (1994) International Governance: Protecting the Environment in a Stateless Society. Ithaca, NY: Cornell University Press.

Young, Oran R. and Gail Osherenko (eds) (1993) Polar Politics: Creating International Environmental Regimes. Ithaca, NY: Cornell University Press.

Zacher, Mark W. and Richard A. Matthew (1992) 'Liberal International Theory: Common Threads, Divergent Strands', paper prepared for the annual meeting of the American Political Science Association, Chicago.

Zürn, Michael (1987) Gerechte internationale Regime. Bedingungen und Restriktionen der Entstehung nicht-hegemonialer internationaler Regime untersucht am Beispiel der Weltkommunikationsordnung. Frankfurt: Haag und Herchen.

Zürn, Michael (1992) Interessen und Institutionen in der internationalen Politik. Spieltheorie, Funktionalismus und internationale Politik. Eine Grundlegung des situationsstrukturellen Ansatzes. Opladen: Leske und Budrich.

Zürn, Michael (1993) 'Bringing the Second Image (Back) In: About the Domestic Sources of Regime Formation', in Volker Rittberger (ed.) Regime Theory and International Relatives, pp. 282-311. Oxford: Clarendon Press. 